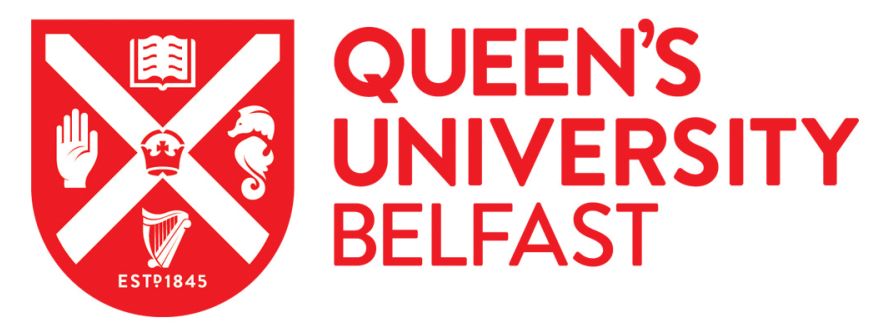

\title{
Larval Anatomy of Andean Toads of the Rhinella spinulosa Group (Anura: Bufonidae)
}

\author{
Vera Candioti, F., Grosso, J., Pereyra, M., Haad, M. B., Lescano, J., Siu-Ting, K., Aguilar, C., \& Baldo, D. \\ (2020). Larval Anatomy of Andean Toads of the Rhinella spinulosa Group (Anura: Bufonidae). Herpetological \\ Monographs. https://doi.org/10.1655/HERPMONOGRAPHS-D-20-00001_hmon-34-01-05_11
}

Published in:

Herpetological Monographs

Document Version:

Peer reviewed version

Queen's University Belfast - Research Portal:

Link to publication record in Queen's University Belfast Research Portal

Publisher rights

Copyright 2020 Herpetologists League. This work is made available online in accordance with the publisher's policies. Please refer to any applicable terms of use of the publisher.

\section{General rights}

Copyright for the publications made accessible via the Queen's University Belfast Research Portal is retained by the author(s) and / or other copyright owners and it is a condition of accessing these publications that users recognise and abide by the legal requirements associated with these rights.

Take down policy

The Research Portal is Queen's institutional repository that provides access to Queen's research output. Every effort has been made to ensure that content in the Research Portal does not infringe any person's rights, or applicable UK laws. If you discover content in the Research Portal that you believe breaches copyright or violates any law, please contact openaccess@qub.ac.uk. 


\section{Herpetological Monographs}

\section{Larval Anatomy of Andean Toads of the Rhinella spinulosa Group (Anura: Bufonidae) --Manuscript Draft--}

\begin{tabular}{|c|c|}
\hline Manuscript Number: & HERPMONOGRAPHS-D-20-00001R2 \\
\hline Article Type: & Research Article \\
\hline Keywords: & Buccal cavity; Chondrocranium; Musculature; Tadpoles \\
\hline Abstract: & $\begin{array}{l}\text { The Rhinella spinulosa group is a clade of toads that inhabit the Andes mountains } \\
\text { from northern Ecuador to Patagonia. Its taxonomy was recently revised, and in its new } \\
\text { arrangement comprises nine species, including Rhinella gallardoi traditionally placed } \\
\text { in a different intrageneric group. In this work we studied the larval external and internal } \\
\text { morphology in this group, by describing for the first time tadpoles of R. achalensis , } \\
\text { R. gallardoi , and R. vellardi , and then summarizing morphological data for R. } \\
\text { altiperuviana , R. limensis, R. papillosa , R. spinulosa , and R. trifolium . } \\
\text { Although we found no diagnostic larval features for the whole clade, two distinct } \\
\text { morphs were identified. Most tadpoles were highly pigmented and slender, and their } \\
\text { oral discs showed a long gap in the second labial tooth row; conversely, tadpoles of R. } \\
\text { limensis and R. vellardi shared a globose body and a very short gap. Buccal and } \\
\text { musculoskeletal features were highly conserved within the group and regarding other } \\
\text { Rhinella , and included four lingual papillae, non-keratinized spurs, tripartite } \\
\text { suprarostral cartilages, quadratoorbital commissure, and in musculature, m. } \\
\text { subarcualis rectus II-IV invading the branchial septum III and laryngeal muscles } \\
\text { reduced or absent. }\end{array}$ \\
\hline
\end{tabular}



Florencia Vera Candioti ${ }^{1,7}$, Jimena Grosso $^{1}$, Martín O. Pereyra $^{2,3}$, M. Belén HaAD $^{1}$, Julián Lescano ${ }^{4}$, KAREN SiU-Ting $^{5,6}$, CÉSAR AguilaR ${ }^{6}$, AND DiEgo BALDO $^{3}$

${ }^{1}$ Unidad Ejecutora Lillo (CONICET - FML), 4000 San Miguel de Tucumán, Argentina

${ }^{2}$ Museo Argentino de Ciencias Naturales "Bernardino Rivadavia” (CONICET), C1405 DJR (CONICET - UNaM), Facultad de Ciencias Exactas, Universidad Nacional de Misiones, 3300

$12{ }^{4}$ Centro de Zoología Aplicada (CONICET), Facultad de Ciencias Exactas, Físicas y Naturales, Universidad Nacional de Córdoba, 5000 Córdoba, Argentina

$14{ }^{5}$ Institute for Global Food Security, School of Biological Sciences, Queen's University Belfast, BT9 5DL Belfast, United Kingdom

${ }^{6}$ Departamento de Herpetología, Museo de Historia Natural, Universidad Nacional Mayor de San

${ }^{7}$ CORRESPONDENCE: e-mail, florivc@gmail.com 
ABSTRACT: The Rhinella spinulosa group is a clade of toads that inhabit the Andes mountains from northern Ecuador to Patagonia. Its taxonomy was recently revised, and in its new arrangement comprises nine species, including Rhinella gallardoi traditionally placed in a different intrageneric group. In this work we studied the larval external and internal morphology in this group, by describing for the first time tadpoles of $R$. achalensis, $R$. gallardoi, and $R$. vellardi, and then summarizing morphological data for $R$. altiperuviana, $R$. limensis, $R$. papillosa, $R$. spinulosa, and $R$. trifolium. Although we found no diagnostic larval features for the whole clade, two distinct morphs were identified. Most tadpoles were highly pigmented and slender, and their oral discs showed a long gap in the second labial tooth row; conversely, tadpoles of $R$. limensis and $R$. vellardi shared a globose body and a very short gap. Buccal and musculoskeletal features were highly conserved within the group and regarding other Rhinella, and included four lingual papillae, non-keratinized spurs, tripartite suprarostral cartilages, quadratoorbital commissure, and in musculature, m. subarcualis rectus II-IV invading the branchial septum III and laryngeal muscles reduced or absent.

Key words: Buccal cavity; Chondrocranium; Musculature; Tadpoles

THE NEOTROPICAL genus of toads Rhinella currently comprises 92 species assigned to seven phenetic groups, the $R$. acrolopha /R. festae, $R$. crucifer, $R$. granulosa, $R$. margaritifera, $R$. marina, R. spinulosa, and R. veraguensis groups (Duellman and Schulte 1992; Pramuk 2006; Grant and Bolivar-G 2014; Moravec et al. 2014), some of which are still poorly diagnosed (Pereyra et al. 2015). The Rhinella spinulosa species group includes medium to large-sized toads, very resistant to dryness and altitude (Cei 1960), distributed on both sides of the Andes mountain range and in sub-Andean mountain systems, from northern Ecuador to the Patagonian forests of southern Argentina and Chile, and from sea level to $5000 \mathrm{~m}$ asl. These toads inhabit and 
reproduce mainly in rivers and streams, oviposit strings of eggs (uniserial, biserial, or multiserial)

47 in a gelatinous tube (see Pereyra et al. 2015), and have exotrophic larvae, which usually develop

48 in lotic environments.

The taxonomy of the species of the Rhinella spinulosa group was highly controversial and different authors disagreed on the specific or subspecific status of some taxa (e.g., Vellard 1959;

Cei 1971; Duellman and Schulte 1992; Córdova 1999; Haas 2002). Traditionally, this group was

composed of nine species: $R$. achalensis, $R$. amabilis, $R$. arequipensis, $R$. arunco, $R$. atacamensis, R. limensis, $R$. rubropunctata, $R$. spinulosa (including several subspecies), and $R$. vellardi (Frost 2019). However, the validity of the group was argued following recent molecular phylogenies that place $R$. arunco and $R$. atacamensis outside of the monophyletic group joining the remaining species (e.g., van Bocxlaer et al. 2010; Pyron 2014; Jetz and Pyron 2018). In addition, $R$. gallardoi is morphologically similar to $R$. spinulosa but it was not assigned to the $R$. spinulosa group due the presence of wide frontoparietals typical of species of the $R$. veraguensis and $R$. margaritifera groups (Carrizo 1992). Recent molecular evidence (M.O. Pereyra, personal observation) supports a restricted monophyletic $R$. spinulosa group composed of nine species: 1 )

61 four original members, i.e., R. achalensis, R. amabilis, R. limensis, and R. vellardi; 2) R.

62 altiperuviana, $R$. papillosa, and $R$. trifolium erected at species level; 3) $R$. spinulosa sensu stricto,

63 including $R$. arequipensis; and 4) $R$. gallardoi now recovered within this group. Features of larval 64 external morphology are known for most of these species (Fernández 1927; Cei 1980; Sinsch

65 1986; Haas 2002; Angulo and Aguilar 2003; Aguilar and Gamarra 2004; Aguilar et al. 2007a), 66 whereas data on internal morphology were described for only two of them (Aguilar and Pacheco 2005; Vera Candioti 2007). In this work we revised larval external and internal morphology of the Rhinella spinulosa group. We first included formal description of the unknown tadpoles of three species $R$. 
70 achalensis, $R$. gallardoi, and $R$. vellardi, and then we compared and summarized morphological

71 descriptions of five more, clarifying taxonomic and nomenclatorial issues in previous literature.

72 We finally explored buccal and musculoskeletal features to discuss the scarce information about

73 larval internal morphology of the $R$. spinulosa group, and compared against what is known in

74 other species groups in Rhinella.

\section{MATERIALS AND METHODS}

We studied 14 lots of tadpoles belonging to eight nominal species (Rhinella achalensis, $R$.

altiperuviana, $R$. gallardoi, $R$. limensis, $R$. papillosa, $R$. spinulosa, $R$. trifolium, and $R$. vellardi), and two populations from Argentina (Catamarca and Mendoza Provinces, now on Rhinella aff. spinulosa CAT and MZA respectively). We collected tadpoles in several localities of Argentina and Perú; their taxonomic identity was confirmed by the combination of specimens reared to metamorphosis, DNA barcoding (16S gen), and unequivocal geographic distributions. We

83 euthanized larvae with the anaesthetic MS222, and preserved them in 4\% formalin. Voucher

84 material is housed at herpetological collections of Laboratorio de Genética Evolutiva (IBS,

85 CONICET - UNaM; LGE), Museo Argentino de Ciencias Naturales (CONICET; MACN), and

86 Museo de Historia Natural (UNMSM; MUSM). Details of each lot are consigned in the 87 Appendix.

We used two to twenty specimens per species (stages 29-38; Gosner 1960) for description and measurements of external morphology with a Leica M205 stereomicroscope. We colored

90 tadpoles with a $1 \%$ solution of methylene blue to enhance visualization of some soft tissues (e.g.,

91 oral structures, spiracle). Measurements follow those proposed by Lavilla (1983) and Altig and

92 McDiarmid (1999): total length, body length, maximum body width, body width at nares, body

93 width at eyes, maximum body height, tail length, tail muscle height, maximum tail height, naris 
94 length, extranarial distance, internarial distance, eye diameter, extraorbital distance, interorbital

95 distance, rostro-spiracular distance, fronto-narial distance, eye-nares distance, oral disc width, 96 dorsal gap width, and ventral gap width.

97 We dissected one to six specimens per species (stages 31-38) for internal anatomy

98 description. We exposed buccopharyngeal cavity through a longitudinal cut below the tadpole

99 eye, and used methylene blue to stain buccal papillae (Wassersug 1976a). For description of the

100 musculoskeletal system, we used specimens cleared and stained according to Wassersug's

101 protocol (1976b). To preserve the muscles from KOH digestion, we interrupted the procedure

102 before that step and used Lugol's stain (Bock and Shear 1972) to visualize orange muscles

103 against blue cartilages. External morphology terminology follows that of Altig and McDiarmid

104 (1999), Altig (2007), and Lannoo (1987) for lateral lines. Terminology for buccal cavity and

105 musculoskeletal features follow those of Wassersug (1976a) and Haas (2003), respectively.

106 Unless they are not available, we used English names for skeletal structures instead of Latin

107 terms.

108

109

RESULTS

110

External Morphology

111

Tadpoles of Rhinella achalensis, $R$. gallardoi, and R. vellardi were fully described in the

112 paragraphs below. Morphological variations in the already described tadpoles of $R$. limensis

113 (Angulo and Aguilar 2003; Aguilar et al. 2007a; as Bufo limensis), R. papillosa (Cei 1980; as B.

114 spinulosus papillosus), R. spinulosa (Aguilar and Gamarra 2004; as B. arequipensis), R. trifolium

115 (Sinsch 1986; Haas 2002; Aguilar and Gamarra 2004; Aguilar et al. 2007a; as R. spinulosus or R.

116 s. flavolineatus, $R$. s. trifolium, and $R$. s. spinulosus), $R$. altiperuviana and $R$. aff. spinulosa CAT 
117 (Fernández 1927; as B. spinulosus), and R. aff. spinulosa MZA (Cei 1980; as B. s. spinulosus) are 118 summarized next.

Rhinella achalensis.-(Figs. 1A, 2A; $n=8$, stages 32-35) Body depressed and oval from

121 dorsal view; maximum width at the otic region. Snout slightly truncate in dorsal view and sloped

122 in lateral view. Ventral body contour with a shallow depression in the gular region and convex in

123 the abdomen. Nostrils large (6.5\% of maximum width of body), dorsal, rounded, with an elevated

124 marginal rim and a triangular medial projection; nostrils closer to the tip of the snout than to the

125 eyes. Eyes large (20\% of maximum width of body) and dorsolateral. Pineal end organ not visible.

126 Spiracle sinistral and placed at the posterior half of the body, short, conical, posterodorsally

127 oriented; external wall slightly folded dorsal and ventrally, giving an appearance of spiracle free

128 from the body wall, but inner wall absent; small oval opening with its major axis oriented

129 dorsoventrally. Gut switchback point medial or slightly displaced to the left of the abdominal

130 cavity. Vent tube short and cylindrical, directed medially and opened dextral, margin fused to the

131 ventral fin. Tail 1.6 longer than the body, with maximum height near to the distal third; dorsal fin

132 originating at the body-tail junction, with the first portion low and almost parallel to the

133 longitudinal body axis and then curved and taller; ventral fin as tall as the dorsal fin and

134 uniformly high; tail tip widely rounded. Tail as high as the body (ratio between body maximum

135 height and maximum tail height is about 1). Caudal musculature thick, tapering distally

136 without reaching the tail tip. Lateral lines not visible. Oral disc (Fig. 2A) large (43\% of maximum

137 width of body), ventral, and emarginated; marginal papillae in a single row, with wide dorsal and

138 ventral gaps ( $84 \%$ and $58 \%$ of the oral disc width, respectively); submarginal papillae scarce (1-

1393 ) and mainly on the upper commissure; jaw sheaths darkly colored, serrated, and with similar

140 width, the upper sheath gently curved with distal ends oriented posterolaterally, and the lower 
141 sheath smaller and V-shaped. Labial tooth row formula 2(2)/3(1); gap in A2 row about 20 teeth

142 wide, and gap in P1 very short, about 4-5 teeth wide; labial teeth are curved, with a wide sheath,

143 scarcely marked neck, and head with 12-14 marginal cusps (Fig. 4A). Coloration: in preserved

144 specimens, dorsum and lateral sides of the body uniformly brown, venter opaque grey and brown

145 with melanophores concentrated on the gular region where the adhesive gland regressed. A dark,

146 straight dorsal line (which in early embryos points out the distribution of cells of the hatching

147 gland) still visible at the analyzed stages, from the nares level to the base of the tail muscles. Tail

148 musculature lighter, lacking melanophores at the muscle-fin junctions; dorsal fin and the

149 posterior third of the ventral with melanophores uniformly distributed, and remaining portions of

150 the ventral fin with disperse melanophores.

151

152

Rhinella gallardoi.-(Figs. 1B, 2B; $n=10$, stages 29-31) Body slightly depressed and oval from dorsal view; maximum width at the otic region. Snout widely truncate in dorsal view

154 and rounded in lateral view. Ventral body contour slightly convex in the abdomen. Nostrils large

155 (7\% of maximum width of body), dorsal, rounded, with a slightly elevated rim and a barely

156 outlined medial projection; nostrils closer to the tip of the snout than to the eyes. Eyes large (17\%

157 of maximum width of body) and dorsolateral. Pineal end organ not visible. Spiracle sinistral and

158 placed at the middle third of the body, short, conical, posterodorsally oriented; inner wall absent

159 and small oval opening with its major axis oriented dorsoventrally. Gut switchback point medial

160 or slightly displaced to the left of the abdominal cavity. Vent tube short and cylindrical, directed

161 medially and opened dextral, margin fused to the ventral fin. Tail is 1.4 larger than the body, with

162 maximum height near to the distal third; dorsal fin originating at the body-tail junction, with the

163 first portion low and almost parallel to the longitudinal body axis and then curved and taller;

164 ventral fin lower than the dorsal fin and uniformly high; tail tip narrowly rounded. Tail slightly 
165 lower than the body (ratio between body maximum height and maximum tail height is about 1.1).

166 Caudal musculature thick, tapering distally without reaching the tail tip. Lateral lines not visible.

167 Oral disc (Fig. 2B) mid-sized (41\% of maximum width of body), ventral, scarcely pigmented,

168 and emarginated; marginal papillae in a single row, with wide dorsal and ventral gaps (83\% and

$16951 \%$ of oral disc width, respectively); submarginal papillae scarce (1-3), on the upper and also

170 frequently on the lower commissure; jaw sheaths darkly colored, serrated, and with similar width,

171 the upper sheath gently curved with distal ends oriented posterolaterally, and the lower sheath

172 smaller and V-shaped. Labial tooth row formula 2(2)/3; gap in A2 row 5-10 teeth wide, P1 and

173 P3 slightly shorter than P2; labial teeth are curved, with a wide sheath, scarcely marked neck, and

174 head with 10-12 marginal cusps (Fig. 4B). Coloration: in preserved specimens, dorsum and

175 lateral sides of the body light brown, venter translucent with a few melanophores scattered on the

176 gular region. A dark, straight dorsal line (which in early embryos points out the distribution of

177 cells of the hatching gland) still visible at the analyzed stages, from the nares level to the otic

178 region. Tail musculature lighter; fins mostly unpigmented, excepting a narrow band at the fin179 muscle junction.

180

$181 \quad$ Rhinella vellardi.-(Figs. 1C, 2C; $n=2$, stage 37) Body slightly depressed and oval from

182 dorsal view; maximum width at the otic region. Snout widely truncate in dorsal view and rounded

183 in lateral view. Ventral body contour slightly convex in the abdomen. Nostrils large (5\% of

184 maximum width of body), dorsal, rounded, with a slightly elevated rim and a barely outlined

185 medial projection; nostrils closer to the tip of the snout than to the eyes. Eyes large (19\% of

186 maximum width of body) and dorsolateral. Pineal end organ not visible. Spiracle sinistral and

187 placed at the middle third of the body, short, conical, posterodorsally oriented; external wall

188 slightly folded dorsal and ventrally, giving an appearance of spiracle free from the body wall, but 
189 inner wall absent; small oval opening with its major axis oriented dorsoventrally. Gut switchback

190 point medial or slightly displaced to the left of the abdominal cavity. Vent tube short and

191 cylindrical, directed medially and opened dextral, margin fused to the ventral fin. Tail 1.5 larger

192 than the body, with maximum height at half its length; dorsal fin originating at the body-tail

193 junction, with the first portion low and almost parallel to the longitudinal body axis and then

194 abruptly curved and taller; ventral fin lower than the dorsal fin and uniformly high; tail tip

195 narrowly rounded. Tail taller than the body (ratio between body maximum height and maximum

196 tail height is about 0.8). Caudal musculature thick, tapering distally without reaching the tail tip.

197 Lateral lines not visible. Oral disc (Fig. 2C) mid-sized (37\% of the body width), ventral, scarcely

198 pigmented, and emarginated; marginal papillae in a single row, with wide dorsal and ventral gaps

199 (81\% and $57 \%$ of oral disc width, respectively); submarginal papillae scarce (1-3) on both

200 commissures; jaw sheaths darkly colored, serrated, and with similar width, the upper sheath

201 gently curved with distal ends oriented posterolaterally, and the lower sheath smaller and V-

202 shaped. Labial tooth row formula 2(2)/3; gap in A2 row about 10 teeth wide, P3 slightly shorter

203 than P2; labial teeth are curved, with a wide sheath, scarcely marked neck, and head with 12-14

204 marginal cusps (Fig. 4G). Coloration: in preserved specimens, dorsum and lateral sides of the

205 body light brown, venter translucent with a few melanophores scattered on the gular and

206 branchial regions. Dark dorsal line outlined between the nares and the otic region. Tail

207 musculature lighter with several unpigmented spots; fins mostly unpigmented, excepting a

208 narrow band at the fin-muscle junction.

Tadpoles of Rhinella altiperuviana, $R$. limensis, $R$. papillosa, $R$. spinulosa, $R$. trifolium,

211 and the two populations of $R$. aff. spinulosa were pictured in Figure 3. All tadpoles had labial

212 tooth row formula (LTRF) 2(2)/3, excepting some specimens of $R$. altiperuviana (3 of 16 
213 tadpoles examined) and $R$. trifolium (2 of 29) that showed LTRF 2(2)/3(1). Submarginal papillae

214 were absent or scarce (1-3) and frequently arranged only in the upper commissures, excepting $R$.

215 limensis where all specimens analyzed had papillae on both commissures. Main variations

216 included body shape and the length of the gap in row A2. Tadpoles of R. limensis had a globose

217 body shape, with high tail fins taller than the body (ratio between body maximum height and

218 maximum tail height about 0.9$)$; the row A2 in these tadpoles showed a very short gap, about 4-5

219 teeth wide. Conversely, tadpoles of $R$. altiperuviana, $R$. papillosa, $R$. spinulosa, $R$. trifolium, and

$220 R$. aff. spinulosa were more streamlined with lower fins (ratio between body maximum height

221 and maximum tail height 1-1.26), body highly pigmented, and the gap in A2 was much longer,

222 about 15-30 teeth wide. Labial teeth were similar in all these taxa (Fig. 4). Lateral lines were

223 usually not evident. The exceptions were $R$. aff. spinulosa MZA, where all lines were visible

224 without staining, $R$. altiperuviana and $R$. papillosa with dorsal lines evident but ventral lines

225 diffuse, and some specimens of $R$. trifolium where dorsal and some ventral lines were visible.

226 Lateral lines of $R$. aff. spinulosa MZA were pictured in Figure 5 and arranged as follows. The

227 dorsal line extended between the midbody, at the level of the origin of the epaxial musculature,

228 and the first third of the dorsal fin. The medial line originated slightly anterior to the dorsal line

229 and ran ventral and parallel through the caudal muscles; it described a wide curve and returned to

230 the dorsal margin of the musculature to almost reach the tip of the tail. The ventral line originated

231 in a medial point in the abdominal region, ran transversely to the side of the body and then

232 directed caudally to end in a region anterior to the limb base; on the left side it was interrupted at

233 the spiracle level. The angular line ran transversely between a ventral point next to the

234 peribranchial wall level and a region below the eye. Four lines originated around the oral disc.

235 The longitudinal oral line originated dorsolateral to the disc and ran caudally for a short tract

236 reaching the eye level; in some specimens it joined the angular line. The oral line began lateral to 
the disc and ran ventral and caudally through the gular region, up to the level of the peribranchial wall; in some specimens this line diverged from the longitudinal oral line. The supraorbital line originated dorsal to the oral disc and ran medial to the nares reaching the posterior margin of the

240 eye. The infraorbital line in turn began dorsolateral to the disc and directed longitudinally below

241 the eye up to its posterior margin. A short postsupraorbital line occurred caudal to the

242 supraorbital line, in some specimens diverging from its posterior edge. Likewise, a very short

243 postinfraorbital line appeared below and posterior to the infraorbital line. Finally, in some specimens an extra line ran longitudinally between the infraorbital and longitudinal oral lines.

\section{Buccopharyngeal Cavity}

The buccal cavity of tadpoles of Rhinella altiperuviana was described by Vera Candioti (2007; as Chaunus spinulosus) and some features of the buccal cavity of $R$. limensis tadpoles were described by Aguilar and Pacheco (2005; as Bufo limensis). In the paragraphs below we described comparatively features of all tadpoles examined in this work. Figures 6 and 7 showed the general aspects and some morphological variations.

On the buccal roof (Figs. 6A, 7A-C), the prenarial arena showed 1-5 pustulations arranged transversely (Rhinella achalensis, $R$. altiperuviana, $R$. gallardoi, $R$. spinulosa, $R$. trifolium, $R$. aff. spinulosa, and some specimens of $R$. limensis) or a transverse ridge (in $R$. papillosa, $R$. vellardi, and some specimens of $R$. limensis). The choanae were large and arranged obliquely at an angle of about $45^{\circ}$ from the longitudinal axis; the anterior margin had small prenarial papillae, and the narial valve was smooth and thick. Three to five paired postnarial papillae were arranged in an inverted V-shape; they were simple and conical, and the second pair was usually the largest; small pustulations were scattered among these papillae. The lateral ridge papillae were well developed, flat, wide, and branched with 2-4 pustulate tips. The median ridge 
was marginally ornamented and varied in shape, including high triangular (in $R$. achalensis, $R$.

262 limensis, $R$. papillosa, $R$. trifolium, $R$. vellardi, and $R$. aff. spinulosa CAT) and rectangular (in $R$.

263 altiperuviana, $R$. gallardoi, $R$. spinulosa, and $R$. aff. spinulosa MZA). The buccal roof arena was

264 defined by 3-5 pairs of papillae, conical or bifurcate; a group of 2-3 papillae or small

265 pustulations diverged laterally from the caudal edge of the arena, parallel to the glandular zone in

266 all species but $R$. gallardoi, $R$. trifolium, and $R$. vellardi. Small pustulations and low papillae

267 were scattered on the buccal roof arena and between roof papillae. The glandular zone was

268 evident in all species, with large secretory pits disposed in a wide U-shaped arrangement. The

269 dorsal velum was short, medially interrupted, smooth (in R. achalensis, $R$. papillosa, R. vellardi,

270 and $R$. aff. spinulosa MZA) or with small marginal papillae (in $R$. atiperuviana, $R$. gallardoi, $R$.

$271 \quad$ limensis, $R$. spinulosa, $R$. trifolium, and $R$. aff. spinulosa CAT).

272 On the buccal floor (Figs. 6B, 7D-F), non-keratinized spurs occurred at the edges of the

273 lower jaw sheath, with curved, medially oriented tips, sometimes bifurcate (Rhinella achalensis

274 and $R$. spinulosa). Paired infralabial papillae were placed on the internal surface of Meckel's

275 cartilage and were wide, flap-like, flat, with 3-4 rounded tips oriented anteriorly; in most

276 specimens a few very small pustulations arranged transversely on the internal aspect of the

277 infrarostral cartilages. On the tongue anlage, four lingual papillae were conical (excepting in the

278 examined specimens of $R$. papillosa, $R$. trifolium, and $R$. vellardi where some were bifid) and

279 tall; laterally, tadpoles of $R$. gallardoi, $R$. limensis, $R$. vellardi, and $R$. aff. spinulosa CAT showed

280 two rounded lingual pads. The buccal floor arena was delimited on both sides by $8-10$ pairs of

281 tall, mostly conical papillae; the papillae nearest to the buccal pockets were the largest and often

282 flat and deeply branched. Several pustulations and low papillae were scattered on the arena and

283 among main papillae. Groups of 3-6 prepocket papillae diverged laterally along the anterior

284 margin of the buccal pockets, and caudally, 3-6 small papillae diverged laterally delimiting the 
anterior edge of the ventral velum. The buccal pockets were elongated and arranged oblique. The ventral velum was semicircular and supported by spicules. Main marginal projections appeared on each side over filter plates, and at the midline where a median notch was absent; the margin was gently undulated in the remaining regions. Secretory pits develop on the ventral margin of the velum, and are mainly noticeable in specimens of $R$. altiperuviana and the two populations of $R$. aff. spinulosa.

\section{Cranial Skeleton}

Aspects of larval cranial skeleton were described only in Rhinella altiperuviana (Vera

294 Candioti 2007; as Chaunus spinulosus). In the paragraphs below we summarized morphological variations in all species examined (Figs. 8, 9).

The neurocranium was almost as wide as long, dorsoventrally flattened, and mostly open dorsally (Figs. 8A,E, 9A-D). The suprarostral cartilage (Figs. 8B,F, 9E,F) had a single, U-shaped medial element dorsally fused to the lateral alae; corpora cartilages appeared comparatively thinner in Rhinella limensis and R. vellardi. Each ala was triangular and had well-developed dorsal anterior and posterior processes. In some specimens of $R$. achalensis, $R$. altiperuviana, $R$. gallardoi, and $R$. spinulosa the suprarostrals showed a narrow proximal connection between ala and corpus. The trabecular horns represented about $23 \%$ of the chondrocranial length, and they

303 diverged describing an angle of $60^{\circ}$ in average; the anterior margins were slightly expanded, and

304 a small lateral trabecular process projected on the ventrolateral margin in all specimens except for

305 R. vellardi. In the ethmoid region, the nasal septum and lamina orbitonasales were outlined in all 306 species excepting $R$. limensis. The orbital cartilages were weak and low with an irregular dorsal 307 margin. The taeniae tecti marginales were slightly chondrified and did not reach the anterior 308 margin of the otic capsules. The optic and oculomotor foramina were defined on the posterior 
309 ends of the cartilage, and the prootic fissure was visible and open dorsally. The large pituitary

310 fenestra was covered by a sheet of chondrified tissue but the carotid foramen was not always

311 completely encircled by cartilage (e.g., in specimens of $R$. gallardoi). The otic capsules were

312 rhomboidal structures that corresponded to about to $27 \%$ the of chondrocranial length; the major

313 axis of each capsule was almost parallel to the chondrocranium longitudinal axis. The fenestra

314 ovalis occurred ventrally and the operculum was not yet developed; the jugular and inferior

315 perilymphatic foramina were visible. The otic capsules were fused to the basicranial floor; they

316 connected to each other dorsally by a thin chondrified tectum synoticum; they showed a thin

317 crista parotica in all species, but a small and pointed anterolateral process was evident only in $R$.

318 achalensis, $R$. altiperuviana, $R$. spinulosa, and $R$. trifolium.

319 The palatoquadrate arranged slightly divergent anteroposteriorly from the

320 chondrocranium longitudinal axis. The articular process was long and wider than the rest of the

321 cartilage; the anterior margin, which articulated with the Meckel's cartilage, was smooth, and a

322 long, thin quadratoethmoid process projected from the medial margin. The muscular process was

323 wide and rounded, and a thick quadratoorbitalis commissure extended between its tip and the

324 base of the quadratoethmoid process. The pseudopterygoid process was absent. The subocular bar

325 expanded posteriorly at the level of the ascending process; the posterior region was concave, with

326 a posterolateral margin angular (more evident in Rhinella achalensis, $R$. altiperuviana, $R$.

327 spinulosa, and $R$. trifolium) or rounded (as in $R$. gallardoi and $R$. limensis), and it showed a thick,

328 dorsal edge that was continuous with the ascending process; a pointed otic process was evident at

329 the posterolateral corner in $R$. achalensis, $R$. spinulosa, and R. trifolium. The ascending process

330 was thin and attached almost perpendicularly to the chondrocranium in an intermediate

331 attachment. The larval otic process was absent (excepting a unilateral process in the analyzed

332 specimen of $R$. vellardi). The fenestra subocularis extended for about $27 \%$ of the chondrocranial 
333 length. In the lower jaw (Fig. 8C,G), Meckel's cartilages were slightly curved, with a dorsolateral

334 edge rounded and a robust retroarticular process; the medial edge had ventromedial and

335 dorsomedial processes. The infrarostral cartilages were paired, thin, and connected medially

336 through an alcianophilic symphysis.

337 In the hyobranchial skeleton (Fig. 8D,H), the ceratohyals were strongly chondrified and

338 had five tall, robust processes. The anterior processes were triangular and oriented slightly lateral;

339 the anterolateral processes were wider, lower, and oriented medially. The posterior processes had

340 a wide base, and their tips diverge slightly lateral contacting the hypobranchial plate. On the

341 lateral edge of the ceratohyals, small lateral processes projected from the anterior margin, and

342 stout articular condyles were seen on the dorsal surface. The pars reuniens joining the ceratohyals

343 was quadrangular, wide, and formed of a different type of cartilage (Fig. 9G); the basibranchial

344 was narrower and shorter, fused to the hypobranchial plate, and had a long, square urobranchial

345 process. The basihyal was absent. The hypobranchial plates were flat and articulate medially

346 leaving a large triangular notch at the posterior region. The four pairs of ceratobranchials were

347 long, thin, and curved, with numerous marginal projections. Ceratobranchials I and II were fused

348 to the hypobranchial plate and had branchial processes; in some specimens of Rhinella achalensis

349 a branchial process III was outlined. In most specimens (excepting $R$. trifolium) ceratobranchial

350 III articulated with the hypobranchial plate through a syndesmotic union. Ceratobranchial IV was

351 not attached to the plate. The ceratobranchials were connected posteriorly by thin terminal

352 commissures; proximal commissures and branchial bridges between ceratobranchials were

353 absent. Dorsally, four long, curved spicules were present, but the fourth was usually very weak

354 and not connected to the ceratobranchial IV; in $R$. altiperuviana and $R$. trifolium there was a

355 cartilaginous bridge joining spicules III and IV (Fig. 9H). 
No cranial ossifications were present at the stages analyzed in most species, excepting

357 frontoparietals, parasphenoid, and exoccipitals that occur in individuals of Rhinella spinulosa

358 (Fig. 9A). Subhyoid ligament was evident in all specimens, on the ventral surface of the

359 ceratohyals (Fig. 10B).

360

361

Musculature

Larval musculature was previously described for Rhinella altiperuviana (Vera Candioti 2007; as Chaunus spinulosus). Muscle configuration was almost identical in all species analyzed,

364 and followed the same pattern already known in other bufonids. Typical features were the $\mathrm{m}$.

365 subarcualis rectus I with three slips, the $\mathrm{m}$. subarcualis rectus II-IV with fibers invading the third

366 branchial septum, the presence of all seven $\mathrm{mm}$. levatores mandibulae, and the absence of $\mathrm{mm}$.

367 mandibulolabialis superior, interhyoideus posterior, diaphragmatopraecordialis, and constrictor

368 and dilatator laryngis. Table 2 summarized descriptions of the 31 muscles as seen in $R$.

369 achalensis, and Figure 10 illustrated some distinct features in the genus. Minor variations in other

370 species were commented in the lines following. Medial and ventral slips of the $\mathrm{m}$. srI were not

371 well defined in R. limensis and R. trifolium. The lateral fibers of the m. srII-IV ran for half the

372 ceratobranchial IV length in $R$. limensis. In $R$. papillosa specimens, some caudal fibers of the $m$.

373 subarcualis obliquus inserted on ceratobranchial III. Subhyoid ligament was not well-developed

374 in $R$. limensis, and fibers of the m. rectus abdominis did not reach it. Finally, a very poorly

375 developed, almost indistinguishable m. dilatator laryngis appeared in one specimen of $R$.

376 trifolium.

377

378

DISCUSSION 
Comparative studies have coincided when highlighting the conservative larval morphology in bufonids (e.g., Haas 2003). Within Rhinella, excepting some clades with distinct features (such as the $R$. veraguensis and $R$. granulosa groups; Blotto et al. 2014; Haad et al. 2014; Grosso et al., in press), the intrageneric groups apparently lack diagnostic larval traits. In our study considering almost all tadpoles now assigned to the Rhinella spinulosa group, we found no diagnostic features for the clade, but two distinct morphs among species. Most tadpoles are highly pigmented and slender, with low tail fins lower or as high as the body, and their oral morphology shows a long gap in the second anterior labial tooth row. This morphology is typical of tadpoles of $R$. achalensis, $R$. altiperuviana, $R$. papillosa, $R$. spinulosa, $R$. trifolium, and the two populations of $R$. aff. spinulosa. Conversely, tadpoles of $R$. limensis and $R$. vellardi share a globose body morphology, high tail fins and a very short gap in tooth row A2. In turn, tadpoles of R. gallardoi have a combination of streamlined body and A2 gap with intermediate length. The original assigning of this species to the $R$. veraguensis group (Carrizo 1992) was not supported by larval morphology, since known tadpoles of this group show a set of distinct external and internal features (e.g., undivided row A2, gular depression or abdominal sucker, adrostral cartilages; Aguayo et al. 2009; Haad et al. 2014), none of which are present in R. gallardoi. While the distinction of two morphs in body shape within the Rhinella spinulosa gr. was not discussed in previous literature, variations in the length of the gap in A2 row were already

397 noticed by Aguilar and collaborators when comparing tadpoles of $R$. limensis with other Peruvian 398 larvae (Angulo and Aguilar 2003; Aguilar and Gamarra 2004; Aguilar et al. 2007a). Interpreting 399 these two characters and their relationship along the phylogenetic hypothesis for the R. spinulosa 400 gr. (M. O. Pereyra, personal observation) shows that the globose morph could define the clade 401 composed of $R$. limensis and $R$. vellardi, and that the slender morph characterizes the large clade 
402 including all the remaining species. A long gap in row A2 would have evolved within this latter,

403 in the clade joining all species but $R$. gallardoi.

404 The oral discs vary slightly in other features as well. These variations are not

405 unambiguously related to the said morphs, and should be checked in wider samples to interpret

406 their distribution. For instance, a small gap in row P1 appeared in $20 \%$ of the analyzed specimens

407 of Rhinella altiperuviana, and was reported in tadpoles of $R$. trifolium (Sinsch 1986), 20\% of $R$.

408 limensis studied by Angulo and Aguilar (2003), and all R. limensis studied by Aguilar and

409 Gamarra (2004). In addition, submarginal papillae were scarce and mostly on the upper

410 commissure in tadpoles with slender morphology, whereas they occurred also in the lower

411 commissure in all the examined globose tadpoles (see also Angulo and Aguilar 2003; Aguilar et

412 al. 2007a) and in some specimens of $R$. aff. spinulosa (Fernández 1927; Cei 1980). Larval

413 measurements were very similar interspecifically, excepting the aforementioned differences in

414 tail and body heights, and an outlined discrimination in naris relative size and position (slightly

415 larger, caudal, and more distant to each other in slender tadpoles).

416 The ecological significance of variations in traits discussed, if any, should be further

417 explored. On one hand, a streamlined body shape is frequent in anuran larvae from lotic

418 environments (e.g., Altig and McDiarmid 1999), including related (e.g., species of the $R$.

419 veraguensis group, Nannophryne cophotis; Aguilar and Gamarra 2004; Aguayo et al. 2009) and

420 unrelated Andean tadpoles (e.g., Telmatobius atahualpai; Aguilar et al. 2007b). However, all

421 tadpoles of $R$. spinulosa group, irrespective of their morphotype, develop in similar water bodies,

422 in general shallow pools and slow-moving rivulets at margins of streams. Additionally, tadpoles

423 with the globose morph inhabit different environments, with $R$. limensis restricted to Peruvian

424 coastal deserts and $R$. vellardi distributed in dry forests at higher elevations (Cei 1972). In this

425 scenario, it seems likely that if an ecomorphological correlation between body shape and type of 
environment occurred, it was early during the evolution of the $R$. spinulosa group, and later diversification allowed for different phenotypes to appear and persist in those same environments. On the other hand, the loss of labial teeth (naturally occurring, in tadpoles affected by pathogens, or after surgery removal) has functional consequences in oral disc kinematics compromising feeding efficiency (Venesky et al. 2010a,b,c). While the differences in length of

431 the gaps in the A2 tooth row of slender vs. globose tadpoles would appear to be too subtle, slight 432 variations in the anchoring of tooth ridges to substrates during foraging cannot be ruled out. Available information on internal morphology of tadpoles of the Rhinella spinulosa group

434 is scarce. Some buccopharyngeal traits were mentioned in R. limensis (Aguilar and Pacheco 2005), and morphology of the buccal cavity and musculoskeletal system were described in larvae of $R$. altiperuviana (Vera Candioti 2007). Rodrigues de Oliveira et al. (2013) studied comparatively buccal features of 12 Rhinella species of several intrageneric groups, and their data allowed for identifying general aspects and some interspecific comparisons. Tadpoles of the Rhinella spinulosa group share with most congeneric species the ornamentation of the prenarial arena, a single pair of infralabial papillae, and four lingual papillae. As noted by Rodrigues de Oliveira et al. (2013), in general infralabial papillae are branched in a distinct way, so that a deep,

442 U-shaped notch bifurcates each papilla leaving uneven halves with secondary projections. In 443 addition, in all tadpoles studied here the skin that covers the distal edges of the infrarostral 444 cartilages folds in a particular manner defining a pair of pointed, curved projections medially 445 oriented. These projections were referred as non-keratinized spurs by Vera Candioti (2007) and 446 Kolenc et al. (2013) in some Rhinella tadpoles, but were not mentioned in descriptions of larvae 447 of the $R$. veraguensis group (Aguayo et al. 2009; Haad et al. 2014). A re-examination of $R$. 448 quechua and R. rumbolli tadpoles revealed very small projections, and scanning electronic 449 micrographs of $R$. abei, R. icterica, and R. ornata in Rodrigues de Oliveira et al. (2013) also 
450 showed them, suggesting that this is a feature universally present in the genus. Unlike in other

451 clades (hylid Scinax, ranid Hoplobatrachus; Grosjean et al. 2004; Alcalde et al. 2011), the spurs

452 are never keratinized in Rhinella tadpoles.

$453 \quad$ Variable buccal features in the genus include the presence and number of infrarostral 454 ornamentation, shape of lingual papillae, extent of papillation of buccal arenas, shape of the 455 median ridge, and configuration of the dorsal and ventral vela (see Tables in Rodrigues de 456 Oliveira et al. 2013). Lingual papillae are in general simple and conical, but Y-shaped papillae 457 appear in tadpoles of Rhinella icterica, $R$. ornata, $R$. pombali, $R$. diptycha, two species of the $R$. 458 granulosa group (Rodrigues de Oliveira et al. 2013), and specimens of R. papillosa and $R$. 459 vellardi here studied. Finally, most tadpoles of the $R$. spinulosa group (excepting the specimens 460 of $R$. gallardoi, R. trifolium, and R. vellardi) have a line of buccal roof arena papillae or 461 pustulations that diverge laterally parallel to the anterior margin of the glandular zone. These are 462 evident in other Rhinella tadpoles (e.g., R. abei, R. crucifer, R. icterica), but further observations 463 with wider samples would confirm whether they are not intraspecifically variable. With the exception of larvae of the Rhinella veraguensis group that show several distinct

465 features (e.g., adrostral cartilages, oblique ascending processes, short and wide articular 466 processes; revised in Haad et al. 2014), the general aspect of the chondrocrania and hyobranchial 467 skeleton is similar among Rhinella tadpoles (e.g., Vera Candioti 2007; Kolenc et al. 2013;

468 Rodrigues de Oliveira et al. 2014). Shared features are the tripartite suprarostral cartilages, 469 quadratoethmoid and lateral trabecular processes present, perpendicular ascending processes, 470 quadratoorbital commissures present, and larval otic process absent. Slight variations, apparently 471 not related to intrageneric groups, are the presence of anterolateral processes of the crista parotica 472 (in $R$. diptycha, $R$. granulosa, and within the $R$. spinulosa group, in $R$. achalensis, $R$. 473 altiperuviana, $R$. spinulosa, and $R$. trifolium), cartilaginous bridges between suprarostral corpus 
474 and alae (in $R$. achalensis, $R$. altiperuviana, $R$. gallardoi, and $R$. spinulosa), and small

475 palatoquadrate otic processes (in $R$. achalensis, $R$. spinulosa, and $R$. trifolium). Likewise,

476 muscular characters are highly conserved in Rhinella and bufonids in general, and the two

477 synapomorphies recovered by Haas (2003) for the family (i.e., m. diaphragmatopraecordialis

478 absent and $\mathrm{m}$. subarcualis rectus II-IV with a lateral, diverging slip) occur in all species of the $R$.

479 spinulosa group. Laryngeal muscles are absent in almost all tadpoles examined here. Although

480 the distribution of these muscles was not analyzed in a phylogenetic context, data on other genera

481 (e.g., Melanophryniscus; Baldo et al. 2014) suggested a widespread absence or deep reduction of

$482 \mathrm{~mm}$. constrictor et dilatator larynges that could be related to the general reduction and late

483 development of lungs in bufonid tadpoles (Haas 2003). Finally, the configuration of the m. rectus

484 abdominis, with medial slips reaching or overpassing the branchial region, seems to be similar in

485 Rhinella tadpoles described; some differences in myotome thickness and packing of fibers could

486 be revealed after detailed quantification, at least regarding tadpoles of the $R$. granulosa group (F.

487 Vera Candioti, personal observation).

488 Finally, three species formerly assigned to the Rhinella spinulosa group, $R$. arunco, $R$.

489 atacamensis, and $R$. rubropunctata, were excluded from the group (M. O. Pereyra, personal

490 observation). Larval external morphology in all of them shows features that are similar to those

491 of the $R$. gallardoi $+R$. spinulosa clade (i.e., a rather slender body and A2 gap mid-sized to long;

492 Cei 1962; Formas and Pugín 1978), but a thorough examination and coding in these and other

493 related Rhinella would be required to assess phylogenetic status for these features.

494 Acknowledgments. - We are grateful to J. Faivovich, S.J. Nenda, and B.L. Blotto

495 (MACN); and P.J. Torres (LGE) for access to collections and institutional specimen loans. We

496 also deeply thank P.J. Venegas (CORBIDI) who provided us the tadpoles of Rhinella vellardi.

497 This work was supported by Agencia Nacional de Promoción Científica y Tecnológica (PICT 
498

499

500

501

502

503

504

505

506

507

508

509

510

511

512

513

514

515

516

517

518

519

520

2015-0813, 2015-2381, 2017-2437, 2018-3349), and a fellowship to KST from the ELEVATE Irish Research Council-MSCA cofund program (ELEVATEPD/2014/69). We thank pertinent national and regional authorities for collecting permits. We thank three anonymous reviewers for their suggestions and corrections that greatly improved our work.

Aguayo, R., E.O. Lavilla, F. Vera Candioti and T. Camacho. 2009. Living in fast-flowing water: Morphology of the gastromyzophorous tadpole of the bufonid Rhinella quechua $(R$. veraguensis group). Journal of Morphology 270:1431-1442.

Aguilar, C., and R. Gamarra. 2004. Descripción de dos renacuajos y una clave para las larvas conocidas del grupo Bufo spinulosus (Anura: Bufonidae) de Perú. Revista Peruana de Biología 11:31-36.

Aguilar, C., and V. Pacheco. 2005. Contribución de la morfología bucofaríngea larval a la filogenia de Batrachophrynus y Telmatobius. Monografías de Herpetología 7:219-238.

Aguilar, C., M. Lundberg, K. Siu-Ting and M.E. Jiménez. 2007a. Nuevos registros para la herpetofauna del departamento de Lima, descripción del renacuajo de Telmatobius rimac Schmidt, 1954 (Anura: Ceratophrydae) y una clave de los anfibios. Revista Peruana de Biología 14:209-216.

Aguilar, C., K. Siu-Ting and P. Venegas. 2007b. The rheophilous tadpole of Telmatobius atahualpai Wiens, 1993 (Anura: Ceratophryidae). South American Journal of Herpetology 2:165-174.

Alcalde, L., F. Vera Candioti, F. Kolenc, C. Borteiro and D. Baldo. 2011. Cranial anatomy of tadpoles of five species of Scinax (Hylidae, Hylinae). Zootaxa 2787:19-36. 
Altig, R. 2007. A primer for the morphology of anuran tadpoles. Herpetological Conservation and Biology 2:71-74.

Altig, R., and R.W. McDiarmid. 1999. Body plan. Development and morphology. Pp. 24-51 in Tadpoles: The Biology of Anuran Larvae (R.W. McDiarmid and R. Altig, eds.). The University of Chicago Press, USA.

Angulo, A., and C. Aguilar. 2003. The tadpole of Bufo limensis (Werner, 1901) (Anura: Bufonidae). Amphibia Reptilia 24:400-405.

Baldo, D., F. Vera Candioti, B. Haad, (...) and M.R. Pie. 2014. Comparative morphology of pond, stream and phytotelm-dwelling tadpoles of the South American Redbelly Toads (Anura: Bufonidae: Melanophryniscus). Biological Journal of the Linnean Society 112:417-441.

Blotto, B., M.O. Pereyra and D. Baldo. 2014. The tadpole of Rhinella azarai (Gallardo, 1965) with comments on the larval morphology in the Rhinella granulosa species group (Anura: Bufonidae). Journal of Herpetology 48:434-438.

Bock, W.J., and C.R. Shear. 1972. A staining method for gross dissection of vertebrate muscles. Anatomischer Anzeiger 130:222-227.

537 Carrizo, G.R. 1992. Cuatro especies nuevas de anuros (Bufonidae: Bufo e Hylidae: Hyla) del norte de la Argentina. Cuadernos de Herpetología 7:14-23.

539 Cei, J.M. 1960. Geographic variation of Bufo spinulosus in Chile. Herpetologica 16:243-250.

540 Cei, J.M. 1962. Batracios de Chile. Ediciones de la Universidad de Chile, Chile.

541 Cei, J.M. 1971. Análisis sero-inmunológico de diferentes niveles de especiación en Bufo del grupo spinulosus. Acta Zoológica Lilloana 28:91-105.

543 Cei, J.M. 1972. Bufo of South America. Pp. 82-92 in Evolution in the Genus Bufo (W.F. Blair, ed.). University of Texas Press, USA. 
545 Cei, J.M. 1980. Amphibians of Argentina. Monitore Zoologico Italiano Monografia 2:1-609.

546 Córdova, J.H. 1999. On karyomorphs, cladistics and taxonomic status of the Bufo spinulosus

547 species group (Amphibia: Anura) in Peru. Stuttgarter Beiträge zur Naturkunde A

$548 \quad$ (Biologie) 600:1-28.

549 Duellman, W.E., and R. Schulte. 1992. Description of a new species of Bufo from northern Peru with comments on phenetic groups of South American toads (Anura: Bufonidae). Copeia 1992:162-172.

552 Fernández, K. 1927. Sobre la biología y reproducción de batracios argentinos. Segunda parte. Boletín de la Academia Nacional de Ciencias de Córdoba 29:271-328.

554 Formas, J.R., and E. Pugín. 1978. Tadpoles of Hylorina sylvatica, Eupsophus vittatus, and Bufo rubropunctatus in southern Chile. Herpetologica 34:355-358.

556 Frost, D.R. 2019. Amphibian Species of the World: an Online Reference. Version 6.0 (Accessed Dec 12 2019). Electronic Database accessible at http://research.amnh.org/herpetology/amphibia/index.html. American Museum of Natural History, New York, USA.

560 Gosner, K.L. 1960. A simplified table for staging anuran embryos and larvae, with notes on identification. Herpetologica 16:183-190.

562 Grant, T., and W. Bolívar-G. 2014. A new species of semiarboreal toad with a salamander-like ear (Anura: Bufonidae: Rhinella). Herpetologica 70:198-210.

564 Grosjean, S., M. Vences and A. Dubois. 2004. Evolutionary significance of oral morphology in the carnivorous tadpoles of tiger frogs, genus Hoplobatrachus (Ranidae). Biological Journal of the Linnean Society 81:171-181. 
Grosso, J., M.O. Pereyra, F. Vera Candioti, N.M. Maciel and D. Baldo. Tadpoles of three species of the Rhinella granulosa group, with a reinterpretation of larval characters. In press in South American Journal of Herpetology.

Haad, M.B., F. Vera Candioti and D. Baldo. 2014. The stream tadpoles of Rhinella rumbolli (Anura: Bufonidae). Herpetologica 70:184-197.

Haas, A. 2003. Phylogeny of frogs as inferred from primarily larval characters (Amphibia: Anura). Cladistics 19:23-89.

Haas, W. 2002. Beitrag zum taxonomischen Status von Bufo trifolium Tschudi, 1845 und Bufo spinulosus flavolineatus Vellard, 1959 sowie zur Biologie von Bufo spinulosus

Jetz, W., and R.A. Pyron. 2018. The interplay of past diversification and evolutionary isolation with present imperilment across the amphibian tree of life. Nature Ecology \& Evolution 2:850-858.

Kolenc, F., C. Borteiro, L. Cotichelli, D. Baldo, C. Martínez Debat and F. Vera Candioti. 2013. The tadpole and karyotype of Rhinella (Bufo) achavali (Anura: Bufonidae). Journal of

Lannoo, M.J. 1987. Neuromast topography in anuran amphibians. Journal of Morphology Herpetology 47:599-606. 191:115-129.

Lavilla, E.O. 1983. Sistemática de Larvas de Telmatobiinae (Anura: Leptodactylidae). Doctoral thesis dissertation, Universidad Nacional de Tucumán, Argentina. 
Pereyra, M.O., F. Vera Candioti, J. Faivovich and D. Baldo. 2015. Egg clutch structure of Rhinella rumbolli (Anura: Bufonidae), a toad from the Yungas of Argentina, with a review of the reproductive diversity in Rhinella. Salamandra 51:161-170.

593 Pramuk, J.B. 2006. Phylogeny of South American Bufo (Anura: Bufonidae) inferred from combined evidence. Zoological Journal of the Linnean Society 146:407-452.

Pyron, R.A. 2014. Biogeographic analysis reveals ancient continental vicariance and recent oceanic dispersal in amphibians. Systematic Biology 63:779-797.

Rodrigues de Oliveira, M.I.R., L.N. Weber and M.F. Napoli. 2013. Internal oral morphology in larvae of the genus Rhinella Fitzinger, 1826 (Amphibia, Anura, Bufonidae). Zootaxa 3745:501-523.

Rodrigues de Oliveira, M.I.R., L.N. Weber and M.F. Napoli. 2014. Chondrocranial and hyobranchial morphology in larvae of the genus Rhinella Fitzinger, 1826 (Amphibia, Anura, Bufonidae). The Herpetological Journal 24:229-237.

Sinsch, U. 1986. Anfibios de la sierra central del Perú, una clave de identificación para adultos y larvas. Boletín de Lima 45:23-33.

Van Bocxlaer, I., S.P. Loader, K. Roelants, S.D. Biju, M. Menegon and F. Bossuyt. 2010. Gradual adaptation toward a range-expansion phenotype initiated the global radiation of toads. Science 327:679-682.

608 Vellard, J. 1959. Estudios sobre batracios andinos V. El género Bufo. Memorias del Museo de 609 Historia Natural "Javier Prado" 8:1-48.

610 Venesky, M.D., R.J. Wassersug and M.J. Parris. 2010a. Fungal pathogen changes the feeding kinematics of larval anurans. Journal of Parasitology 96:552-557. 
612 Venesky, M.D., R.J. Wassersug and M.J. Parris. 2010b. How does a change in labial tooth row

613 number affect feeding kinematics and foraging performance of a ranid tadpole (Lithobates 614 sphenocephalus)? The Biological Bulletin 218:160-168.

615 Venesky, M.D., R.J. Wassersug and M.J. Parris. 2010c. The impact of variation in labial tooth 616 number on the feeding kinematics of tadpoles of Southern Leopard Frog (Lithobates 617 sphenocephalus). Copeia 2010:481-486.

618 Vera Candioti, M.F. 2007. Anatomy of anuran tadpoles from lentic water bodies: systematic 619 relevance and correlation with feeding habits. Zootaxa 1600:1-175.

620 Wassersug, R.J. 1976a. Oral morphology of anuran larvae: terminology and general description. 621 Occasional Papers of the Museum of Natural History, University of Kansas 48:1-23.

622 Wassersug, R.J. 1976b. A procedure for differential staining of cartilage and bone in whole 623 formalin fixed vertebrates. Stain Technology 51:131-134. 
APPENDIX

Specimens Examined

Achala, Puesto Cuello near to El Volcán, LGE 04235, $n=14$, stages 32-36. Skeleton (6, 35-36);

Rhinella altiperuviana.-ARGENTINA: JUJUY: Departamento Humahuaca: Chucalezna,

630 Río Grande, Quebrada de Humahuaca, LGE 03871 and Departamento Susques: Susques, Salar de

631 Olaroz, LGE 22111, $n=16$, stages 35-38. Skeleton $(4,35)$; muscles $(2,35$ and 36); buccal cavity $632(1,37)$.

Rhinella gallardoi._ARGENTINA: JUJUY: Departamento Doctor Manuel Belgrano:

634 Tilquiza, LGE 09887, $n=11$, stages 29-31. Skeleton $(2,31)$; muscles $(1,31)$; buccal cavity (1, $63531)$.

636 Rhinella limensis._PERÚ: LA LIBERTAD: Cajabamba, Sanagorán, LGE 22101 and LIMA: 637 Provincia Huarochirí: Barba Blanca, LGE 22102, $n=5$, stages 30-38. Skeleton (1, 33); muscles 638 (2, 33 and 35); buccal cavity $(1,33)$.

639 Rhinella papillosa.-ARGENTINA: NEUQUÉN : Departamento Minas: Camalón, MACN $64050401, n=17$, stages 30-31. Skeleton $(2,31)$; muscles $(1,31)$; buccal cavity $(1,31)$.

641 Rhinella spinulosa._PERÚ: AREQUIPA: Provincia Arequipa: Sabandía, LGE 22103, $n=$ 642 2, stages 37. Skeleton (1); muscles (2); buccal cavity (1).

643 Rhinella trifolium.-PERÚ: PASCO: Paucartambo, MUSM 17815-6, LGE 22104, $n=29$, 644 stages 30-34. Skeleton (2, 33); muscles (2, 34); buccal cavity $(2,34)$.

645 Rhinella vellardi._PERÚ: AMAZONAS: Provincia Chachapoyas: Balsas, Quebrada 646 Honda, LGE 22105, $n=2$, stages 37. Skeleton (1); muscles (1); buccal cavity (1). 
648 Capillitas, LGE 22112, $n=7$, stages 31-38. Skeleton (1, 37); muscles (1,37-38); buccal cavity

649 (1, 37); MEndozA: Departamento Malargüe: Ruta Provincial N 226, on the way to Paso

650 Vergara, margins of the Río Valenzuela, LGE 17106, $n=6$, stages 35-38. Skeleton (2, 35);

651 muscles $(1,37)$; buccal cavity $(1,37)$. 
652 TABLE 1.-External morphology measurements, presented as average (standard deviation), in species of the Rhinella spinulosa group.

653 The two last columns correspond to populations of $R$. aff. spinulosa from Argentinean Provinces Catamarca and Mendoza (CAT and

654 MZA respectively).

\begin{tabular}{|c|c|c|c|c|c|c|c|c|c|c|}
\hline & R. achalensis & R. altiperuvian & R. gallardoi & R. limensis & R. papillosa & R. spinulosa & R. trifolium & R. vellardi & R. CAT & $R$. MZA \\
\hline & $n=8$ & $n=10$ & $n=10$ & $n=3$ & $n=10$ & $n=1$ & $n=10$ & $n=1$ & $n=7$ & $n=7$ \\
\hline & stages $32-33$ & stages $36-37$ & stages $30-37$ & stages $30-37$ & stages $30-31$ & stage 36 & stages $32-34$ & stage 36 & stages $30-32$ & stages $35-37$ \\
\hline Snout vent length & $8.80(0.39)$ & $13.86(0.78)$ & $9.92(1.03)$ & $12.86(0.80)$ & $8.94(0.29)$ & 11.89 & $9.14(0.71)$ & 11.49 & $8.65(0.47)$ & $12.27(1.70)$ \\
\hline Maximum body height & $3.98(0.37)$ & $6.60(0.42)$ & $4.66(0.79)$ & $6.55(0.77)$ & $4.69(0.20)$ & 5.82 & $4.36(0.33)$ & 5.23 & $4.41(0.22)$ & $5.84(0.84)$ \\
\hline Maximum body width & $5.07(0.41)$ & $8.73(0.74)$ & $5.70(0.92)$ & $8.32(0.54)$ & $5.53(0.22)$ & 7.67 & $5.67(0.35)$ & 6.94 & $4.95(0.22)$ & $7.37(1.05)$ \\
\hline Body width at eyes & $4.37(0.24)$ & $6.52(0.47)$ & $4.67(0.60)$ & $6.69(0.29)$ & $4.50(0.17)$ & 6.06 & $4.63(0.30)$ & 5.89 & $4.13(0.30)$ & $5.67(0.77)$ \\
\hline Body width at nares & $3.01(0.17)$ & $4.66(0.36)$ & $3.25(0.39)$ & $4.60(0.20)$ & $3.18(0.15)$ & 4.29 & $2.91(0.23)$ & 3.89 & $2.80(0.22)$ & $4.08(0.57)$ \\
\hline Dorsal gap width & $1.83(0.12)$ & $2.42(0.16)$ & $1.92(0.13)$ & $2.15(0.10)$ & $1.74(0.07)$ & 2.09 & $1.6(0,11)$ & 2.08 & $1.73(0.16)$ & $2.30(0.26)$ \\
\hline Eye diameter & $1.01(0.06)$ & $1.28(0.17)$ & $0.95(0.22)$ & $1.33(0.13)$ & $0.91(0.04)$ & 1.20 & $1.06(0.11)$ & 1.35 & $0.92(0.08)$ & $1.21(0.17)$ \\
\hline Eye-nares distance & $1.69(0.08)$ & $2.54(0.14)$ & $1.88(0.12)$ & $2.54(0.21)$ & $1.66(0.09)$ & 2.39 & $2.12(0.10)$ & 1.79 & $1.84(0.13)$ & $2.45(1.00)$ \\
\hline Extraorbital distance & $3.09(0.10)$ & $4.46(0.26)$ & $2.88(0.57)$ & $4.52(0.48)$ & $2.90(0.09)$ & 3.90 & $3.33(0,25)$ & 3.80 & $2.92(0.35)$ & $4.09(0.59)$ \\
\hline Fronto-narial distance & $0.57(0.10)$ & $1.01(0.19)$ & $0.70(0.17)$ & $0.84(0.04)$ & $0.83(0.12)$ & 0.86 & $0.72(0,10)$ & 0.65 & $0.58(0.09)$ & $1.19(0.26)$ \\
\hline Internarial distance & $1.20(0.09)$ & $1.66(0.13)$ & $1.36(0.07)$ & $1.97(0.17)$ & $1.14(0.04)$ & 1.52 & $1.48(0.08)$ & 1.16 & $1.21(0.13)$ & $1.83(0.74)$ \\
\hline Interorbital distance & $1.89(0.26)$ & $3.39(0.21)$ & $1.72(0.55)$ & $3.43(0.28)$ & $1.92(0.13)$ & 2.99 & $2.08(0.14)$ & 1.90 & $1.94(0.18)$ & $3.00(0.40)$ \\
\hline
\end{tabular}




\begin{tabular}{|c|c|c|c|c|c|c|c|c|c|c|}
\hline Maximum tail height & $4.04(0.30)$ & $5.32(0.35)$ & $4.27(0.70)$ & $6.74(0.70)$ & $4.00(0.16)$ & 5.74 & $4.33(0.25)$ & 6.19 & $3.49(0.28)$ & $5.47(0.79)$ \\
\hline Naris length & $0.33(0.10)$ & $0.50(0.09)$ & $0.38(0.09)$ & $0.50(0.09)$ & $0.37(0.03)$ & 0.59 & $0.5(0.06)$ & 0.35 & $0.44(0.06)$ & $0.55(0.40)$ \\
\hline Oral disc width & $2.17(0.12)$ & $2.89(0.20)$ & $2.32(0.17)$ & $2.74(0.27)$ & $1.91(0.08)$ & 2.54 & $2.04(0.09)$ & 2.56 & $2.09(0.16)$ & $2.71(0.19)$ \\
\hline Rostro-spiracular distance & $5.40(0.19)$ & $7.14(0.62)$ & $5.22(0.65)$ & $7.18(0.64)$ & $4.81(0.31)$ & 6.51 & $5.31(0.48)$ & 6.31 & $5.17(0.27)$ & $6.74(0.93)$ \\
\hline Tail length & $14.14(0.42)$ & $21.88(1.24)$ & $15.14(1.12)$ & $20.10(5.15)$ & $12.38(0.51)$ & 18.37 & $14.84(1.36)$ & 16.98 & $13.74(1.33)$ & $19.00(2.72)$ \\
\hline Total length & $22.94(0.53)$ & $35.85(1.83)$ & $24.02(3.62)$ & $26.26(11.94)$ & $20.44(2.69)$ & 30.25 & $23.98(1.98)$ & 30.25 & $20.13(3.72)$ & $28.91(4.69)$ \\
\hline Tail muscle height & $1.65(0.10)$ & $2.62(0.18)$ & $2.07(0.14)$ & $3.07(0.41)$ & $1.57(0.11)$ & 2.86 & $1.84(0.13)$ & 2.11 & $1.91(0.11)$ & $2.47(0.47)$ \\
\hline Ventral gap width & $1.27(0.12)$ & $1.62(0.25)$ & $1.19(0.16)$ & $1.60(0.14)$ & $1.01(0.06)$ & 1.12 & $0.95(0.09)$ & 1.45 & $1.22(0.16)$ & $1.75(0.26)$ \\
\hline
\end{tabular}



TABLE 2.- Larval musculature in Rhinella achalensis.

\begin{tabular}{|c|c|}
\hline Muscle & Attachments \\
\hline Levator mandibulae longus superficialis & $\begin{array}{l}\text { posterolateral margin of subocular bar - dorsomedial } \\
\text { edge of Meckel's cartilage }\end{array}$ \\
\hline Levator mandibulae longus profundus & $\begin{array}{l}\text { posterolateral margin of subocular bar, ventral to } \\
\text { levator mandibulae longus superficialis - frontal } \\
\text { aspect of suprarostral ala, next to lateral margin, } \\
\text { through a long, thin tendon }\end{array}$ \\
\hline Levator mandibulae externus superficialis & $\begin{array}{l}\text { medial point at the ascending margin of muscular } \\
\text { process, at about half its length - posterior surface of } \\
\text { the dorsolateral edge of suprarostral ala; ramus V3 is } \\
\text { ventral to this muscle }\end{array}$ \\
\hline Levator mandibulae externus profundus & $\begin{array}{l}\text { inner surface of the ascending margin of muscular } \\
\text { process, at about half its length - frontal surface of } \\
\text { suprarostral ala, next to lateral margin, through a } \\
\text { tendon common with that of levator mandibulae } \\
\text { longus profundus }\end{array}$ \\
\hline Levator mandibulae internus & $\begin{array}{l}\text { ventral surface of the ascending process and } \\
\text { anteroventral surface of the otic capsule - } \\
\text { dorsolateral edge of Meckel's cartilage }\end{array}$ \\
\hline Levator mandibulae articularis & $\begin{array}{l}\text { inner surface of muscular process, ventral to levator } \\
\text { mandibulae externus profundus - dorsolateral edge of } \\
\text { Meckel's cartilage, medial to levator mandibulae }\end{array}$ \\
\hline
\end{tabular}




\section{internus}

Levator mandibulae lateralis

Mandibulolabialis

Intermandibularis

Submentalis

Orbitohyoideus

Suspensoriohyoideus

Hyoangularis

Suspensorioangularis

Quadratoangularis

Interhyoideus

Geniohyoideus lateral edge of articular process -dorsolateral edge of suprarostral ala

ventromedial edge of Meckel's cartilage - lower lip, in a small, mental area

ventrolateral edge of Meckel's cartilage - median aponeurosis attached to the ventral skin ventral surface of infrarostral cartilages dorsal edge of muscular process -lateral edge of ceratohyal inferior region of the ascending margin of muscular process -posterolateral surface of the lateral edge of ceratohyal

dorsal surface of lateral process of ceratohyal retroarticular process ventral half of the descending margin of muscular process - posterolateral surface of the lateral edge of ceratohyal; it occupies the lower half of muscular process ventral surface of muscular process - retroarticular process lateral edge of ceratohyal - median aponeurosis ventral surface of infrarostral - hypobranchial plate 
at the level of ceratobranchial III

Constrictor branchialis II

branchial process II - terminal commissure I;

disposed on ceratobranchial I

Constrictor branchialis III

branchial process II - terminal commissure II;

disposed on ceratobranchial II

Constrictor branchialis IV

branchial process II - distal edge of ceratobranchial

III; disposed on ceratobranchial III

Levator arcuum branchialium I

lateral margin of subocular bar - lateral margin of

ceratobranchial I

Levator arcuum branchialium II

posterolateral margin of subocular bar -terminal

commissure I

Levator arcuum branchialium III

lateral and posterolateral margins of otic capsule -

terminal commissure II; a posterior slip inserts more

dorsally on the capsule

Levator arcuum branchialium IV

ventral surface of otic capsule - medial distal margin

of ceratobranchial IV

Tympanopharyngeus

a few fibers that diverge medially from levator arcuum branchialium IV, to insert on the connective tissue anterior to glottis

Subarcualis rectus I

three slips originated at the posterior surface of the

posterior process of the ceratohyal; ventral slip

inserts on branchial process III, middle slip on

branchial process II, and dorsal slip on proximal area 
Subarcualis rectus II-IV

Subarcualis obliquus

Rectus cervicis

Diaphragmatobranchialis

Rectus abdominalis of ceratobranchial I. The distinction between middle and ventral slips is not well defined at the insertion on ceratohyal ceratobranchial II -lateral margin of proximal area of ceratobranchial IV; very thin. At the anterior insertion, some fibers are continuous with those of ceratobranchial II; at the posterior insertion, a thin slip diverges laterally following the ceratobranchial reaching its distal edge urobranchial process - branchial process II branchial process III - peribranchial peritoneum; short and thin distal edge of ceratobranchial III - peribranchial peritoneum; short and very thin pelvic girdle - peritoneum. Lateral slips originate at the level of spiracle, and middle slips reach the pericardic region; more medial slips form a compact slip that continues as a fibrous connective tissue that reaches the subhyoid ligament, whereas the remaining medial fibers are loose and insert caudal and dorsally on the diaphragm 
FIG. 1.- The tadpoles of (A) Rhinella achalensis (stage 33, LGE 04235), (B) R. gallardoi

660 (stage 31, LGE 09887), and (C) R. vellardi (stage 37, LGE 22105), showing lateral, dorsal, and 661 ventral views. Scale bars $=1 \mathrm{~mm}$.

662

663

FIG. 2.-Details of the oral discs of same specimens of (A) Rhinella achalensis, (B) $R$. 665 gallardoi, and (C) R. vellardi. Scale bars $=0.5 \mathrm{~mm}$.

FIG. 3.-Comparative external morphology in tadpoles of the Rhinella spinulosa group.

669 Lateral views and detail of the oral disc are shown. (A) R. altiperuviana (stage 37, LGE 22111),

670 (B) R. limensis (stage 34, LGE 22101), (C) R. papillosa (stage 31, MACN 50401), (D) $R$.

671 spinulosa (stage 37, LGE 22103), (E) R. trifolium (stage 32, MUSM 17815-6), (F) $R$. aff.

672 spinulosa CAT (stage 31, LGE 22112), (G) R. aff. spinulosa MZA (stage 38, LGE 17106). Scale

673 bars $=1 \mathrm{~mm}$. Note the two morphotypes differentiating the tadpoles of $R$. limensis (globose body

674 and small gap in A2) vs. all the remaining tadpoles (slender bodies and larger gaps in A2).

FIG. 4.- Labial tooth morphology in tadpoles of the Rhinella spinulosa group, lateral

678 views of individual teeth and details of head cusps. (A) R. achalensis (stage 33, LGE 04235), (B)

679 R. altiperuviana (stage 37, LGE 22111), (C) R. gallardoi (stage 31, LGE 09887), (D) R. limensis

680 (stage 34, LGE 22101), (E) R. papillosa (stage 31, MACN 50401), (F) R. spinulosa (stage 37,

681 LGE 22103), (G) R. trifolium (stage 32, MUSM 17815-6), (H) R. vellardi (stage 37, LGE 
22105), (I) $R$. aff. spinulosa CAT (stage 31, LGE 22112), (J) $R$. aff. spinulosa MZA (stage 38,

683 LGE 17106). Scale bars, main divisions $=0.05 \mathrm{~mm}$. Note the similar curved teeth with numerous 684 marginal cusps.

FIG. 5.-Lateral lines, as seen in a tadpole of Rhinella aff. spinulosa MZA (stage 37, LGE 17106). $\mathrm{AN}=$ angular, $\mathrm{D}=$ dorsal, $\mathrm{IO}=$ infraorbital, $\mathrm{LOR}=$ longitudinal oral, $\mathrm{M}=$ median, $\mathrm{OR}=$ oral, $\mathrm{PIO}=$ postinfraorbital, $\mathrm{PSO}=$ postsupraorbital, $\mathrm{SO}=$ supraorbital, $\mathrm{V}=$ ventral.

FIG. 6.-Buccal roof (A) and floor (B) of Rhinella achalensis (stage 34, LGE 04235).

$693 \mathrm{BFAP}=$ buccal floor arena papillae, $\mathrm{BP}=$ buccal pocket, $\mathrm{BRAP}=$ buccal roof arena papillae, $\mathrm{DV}$

694 = dorsal velum, $\mathrm{GZ}=$ glandular zone, $\mathrm{ILP}=$ papillae, $\mathrm{IN}=$ internal nare, $\mathrm{LP}=$ lingual papillae,

$695 \mathrm{LRP}=$ lateral ridge papilla, $\mathrm{MR}=$ median ridge, $\mathrm{PNA}=$ prenarial arena, $\mathrm{PPP}=$ prepocket

696 papillae, $\mathrm{PTNP}=$ postnarial papillae, $\mathrm{S}=$ spur, $\mathrm{VV}=$ ventral velum. Scale bars $=1 \mathrm{~mm}$.

FIG. 7.-Details of buccal cavities of other species of the Rhinella spinulosa group,

700 showing some distinctive features. Anterior region of the buccal roof of (A) R. papillosa (stage

701 31, MACN 50401) and (B) R. spinulosa (stage 37, LGE 22103); note the different shapes of the

702 median ridges. (C) Posterior region of the buccal roof of $R$. limensis (stage 33, LGE 22102),

703 showing the dorsal velum and glandular zone. (D) Anterior region of the buccal floor of $R$.

704 altiperuviana (stage 37, LGE 22111), showing the spurs, infralabial and lingual papillae. (E)

705 Detail of the tongue anlage of $R$. gallardoi (stage 31, LGE 09887), showing the lingual pads on 
both sides of the tongue. (F) Detail of the buccal pockets of $R$. aff. spinulosa CAT (stage 37, LGE 22112), showing the prepocket papillae and general papillae of the floor arena. BFAP $=$ buccal floor arena papillae, $\mathrm{BP}=$ buccal pocket, $\mathrm{DV}=$ dorsal velum, ILP = infralabial papillae, $\mathrm{LP}=$ lingual papillae, $\mathrm{LRP}=$ lateral ridge papilla, $\mathrm{MR}=$ median ridge, $\mathrm{P}=$ lingual pad, $\mathrm{PPP}=$ prepocket papillae, $\mathrm{S}=$ spur, $\mathrm{SP}=$ secretory pits. Scale bars $=1 \mathrm{~mm}$.

FIG. 8.- Larval skeleton in Rhinella achalensis (stage 35, LGE 04235) and R. gallardoi (stage 31, LGE 09887). (A,E) Chondrocranium; (B,F) Suprarostral cartilage; (C,G). Lower jaw cartilages; $(\mathrm{D}, \mathrm{H})$ Hyobranchial skeleton. $\mathrm{A}=$ ala, $\mathrm{AP}=$ articular process, $\mathrm{ASP}=$ ascending process, $\mathrm{C}=$ corpus, $\mathrm{CB}=$ ceratobranchials, $\mathrm{CH}=$ ceratohyals, $\mathrm{HP}=$ hypobranchial plate, $\mathrm{IR}=$ infrarostral cartilage, $\mathrm{LT}=$ lateral trabecular process, $\mathrm{MC}=$ Meckel's cartilage, $\mathrm{MP}=$ muscular process, $\mathrm{OC}=$ otic capsule, $\mathrm{PAL}=$ anterolateral process of the otic capsule, $\mathrm{PQ}=$ palatoquadrate,

$719 \mathrm{PR}=$ pars reuniens, $\mathrm{QEP}=$ quadratoethmoid process, $\mathrm{QOC}=$ quadratoorbital commissure, $\mathrm{SB}=$ 720 subocular bar, $\mathrm{TH}=$ trabecular horns, $\mathrm{TS}=$ tectum synoticum. Scale bars $=0.5 \mathrm{~mm}$.

721 Chondrocrania are very similar, excepting the angular margin of subocular bar and the small anterolateral process of the otic capsules in $R$. achalensis.

FIG. 9.-Details of larval skeletons of other species of the Rhinella spinulosa group,

726 showing some distinctive features (asterisks). Chondrocranium in (A) R. spinulosa (stage 37,

727 LGE 22103), ventral view; note the small processes in the subocular bars and the otic capsules.

728 (B) $R$. papillosa (stage 31, MACN 50401), ventral view; (C) $R$. aff. spinulosa MZA (stage 35,

729 LGE 17106), dorsal view; note the pointed lateral trabecular processes in the two species. (D) $R$. 
730 vellardi (stage 37, LGE 22105), ventral view; note the thin, unilateral larval otic process.

731 Suprarostral cartilages in frontal view of (E) R. limensis (stage 33, LGE 22102) and (F) $R$.

732 spinulosa (stage 37, LGE 22103); note the cartilaginous bridges between corpus and ala in the

733 latter. (G) Detail of pars reuniens of the specimen of $R$. spinulosa, showing the different type of

734 cartilaginous tissue. (H) Detail of four spicules in $R$. altiperuviana (stage 35, LGE 22111),

735 showing the cartilage bridge between spicules III and IV. Scale bars $=1 \mathrm{~mm}$.

FIG. 10.-Larval cranial musculature in tadpoles of species of the Rhinella spinulosa

739 group. (A) Lateral view of the muscular process of $R$. gallardoi (stage 31, LGE 09887), showing

740 details of mm. levatores mandibulae; thin levator mandibulae lateralis and externus superficialis

741 are present in all species. (B) Ventral view of the mandibular region of $R$. aff. spinulosa CAT

742 (stage 37, LGE 22112), showing ventral muscles and the subhyoid ligament; when the ventral

743 skin is lifted, the attachment of the anterior portion of the $\mathrm{m}$. intermandibularis to the lower lip

744 skin is evident. (C) Ventral view of the left branchial basket of $R$. altiperuviana (stage 35, LGE

745 22111), showing branchial muscles; note the lateral slip of the m. subarcualis rectus II-IV

746 invading the third branchial septum in a constrictor-like arrangement. (D) Detail of the left

747 branchial basket of $R$. aff. spinulosa MZA (stage 37, LGE 17106), showing the three slips of the

$748 \mathrm{~m}$. subarcualis rectus I. (E) Ventral view of the abdominal region of the specimen of $R$. gallardoi,

749 showing the general configuration of the m. rectus abdominis with three types of fibers. CBII-IV

$750=$ constrictor branchialis II-IV, $\mathrm{GH}=$ geniohyoideus, $\mathrm{HA}=$ hyoangularis, $\mathrm{IM}=$

751 intermandibularis, LIG SH = subhyoid ligament, LMA = levator mandibulae articularis, LMEP =

752 levator mandibulae externus profundus, LMES = levator mandibulae externus superficialis, LML

753 = levator mandibulae lateralis, $\mathrm{LMLS}=$ levator mandibulae longus superficialis, MLI = 
754 mandibulolabialis inferior, $\mathrm{OH}=$ orbitohyoideus, $\mathrm{QA}=$ quadratoangularis, $\mathrm{RAL}=$ rectus

755 abdominis lateral fibers, RAM1 = rectus abdominis medial, compact fibers, RAM2 = rectus

756 abdominis medial, loose fibers, $\mathrm{SO}=$ subarcualis obliquus, $\mathrm{SRI}=$ subarcualis rectus I, SRID =

757 subarcualis rectus I dorsal slip, SRII-IV = subarcualis rectus II-IV, SRIM = subarcualis rectus I

758 median slip, SRIV = subarcualis rectus I ventral slip, V3 = mandibular branch of the trigeminal

759 nerve. Scale bars $=0.5 \mathrm{~mm}$ excepting $(\mathrm{E}), 1 \mathrm{~mm}$. 


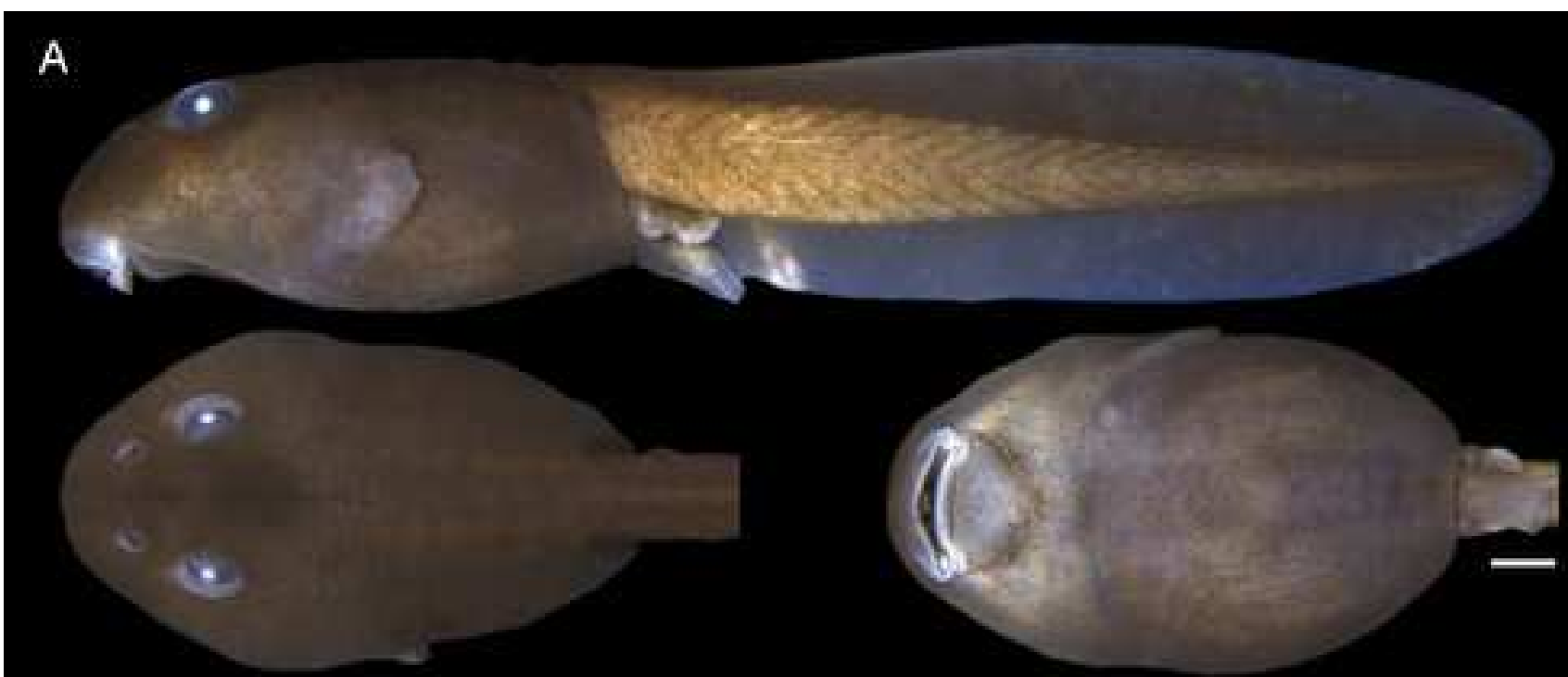

B

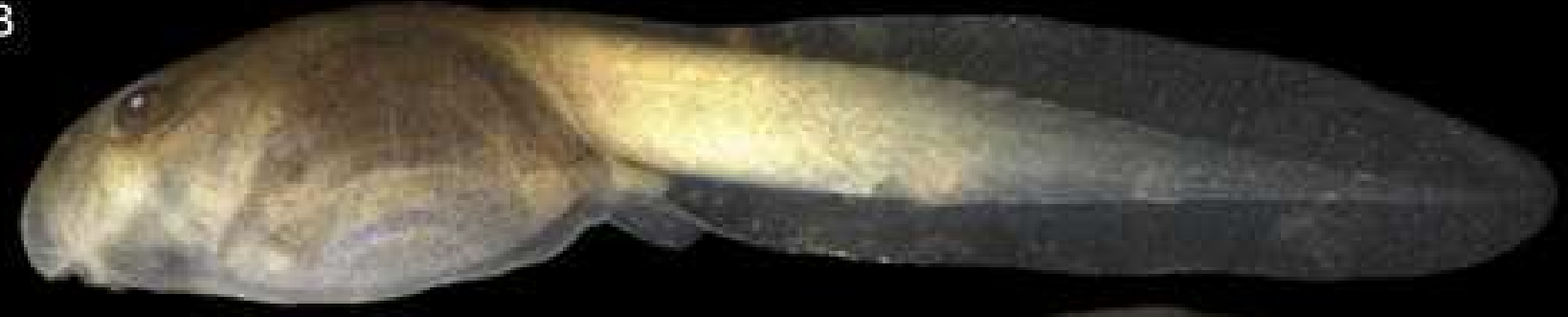

C
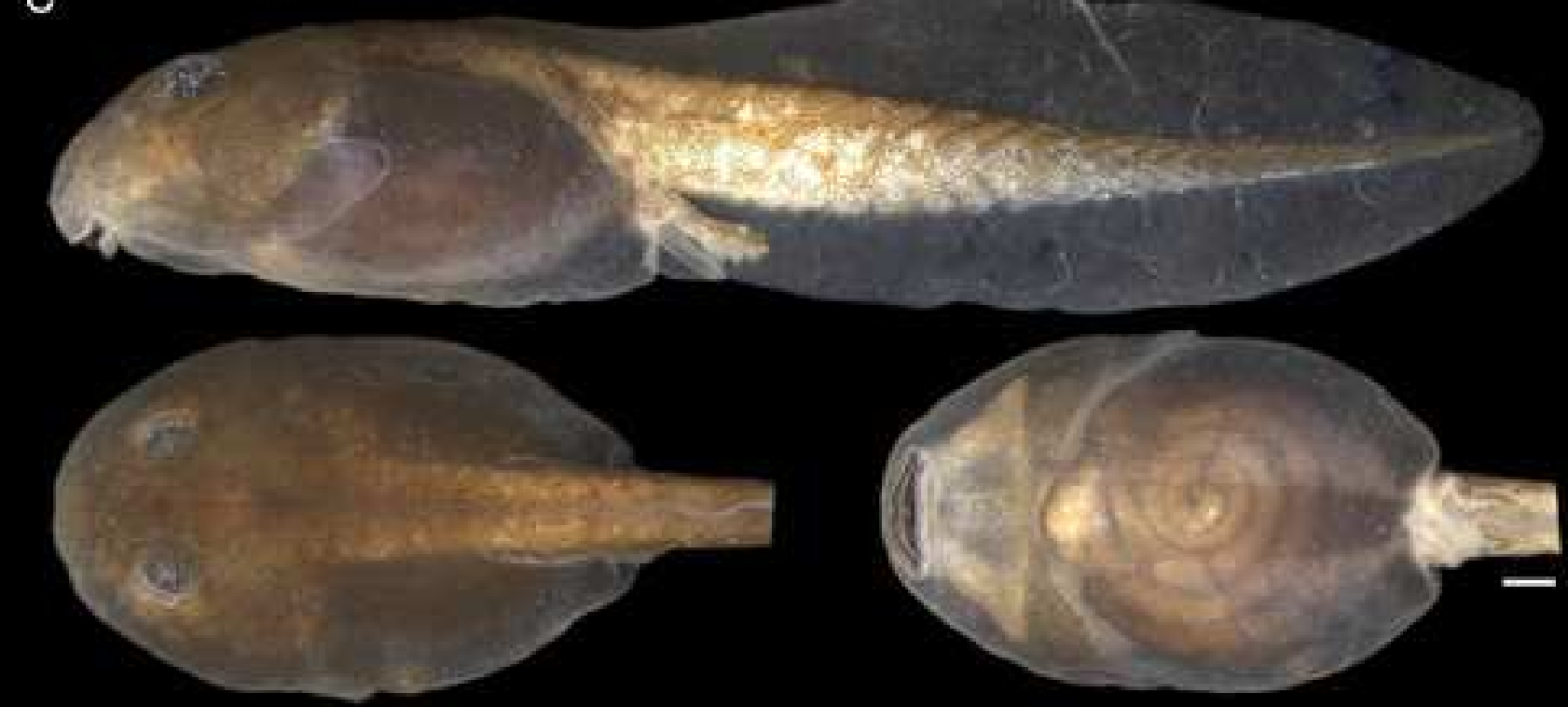

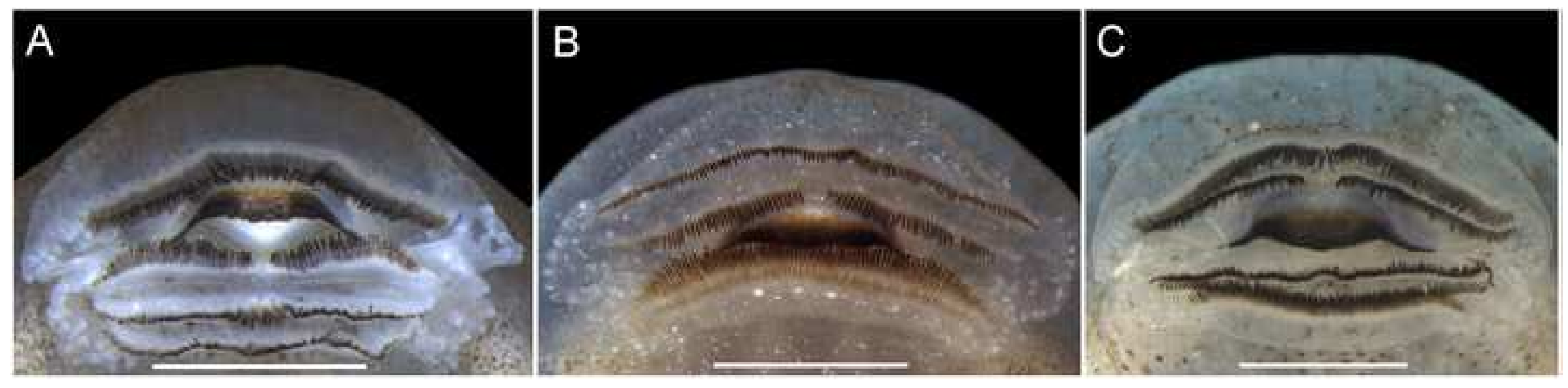

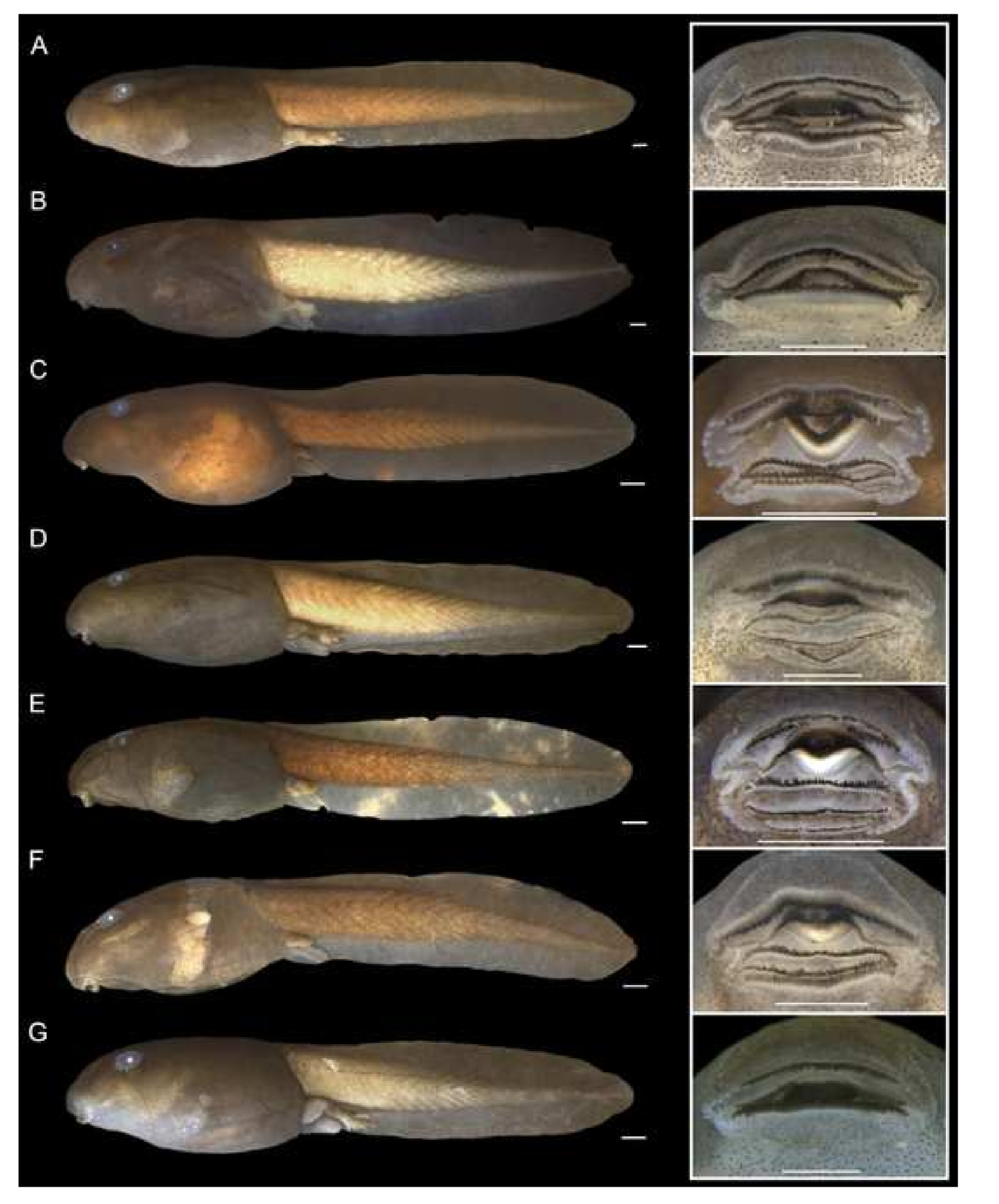

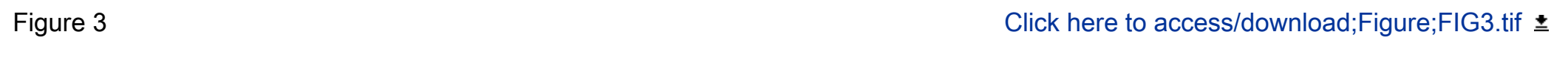
政 . 


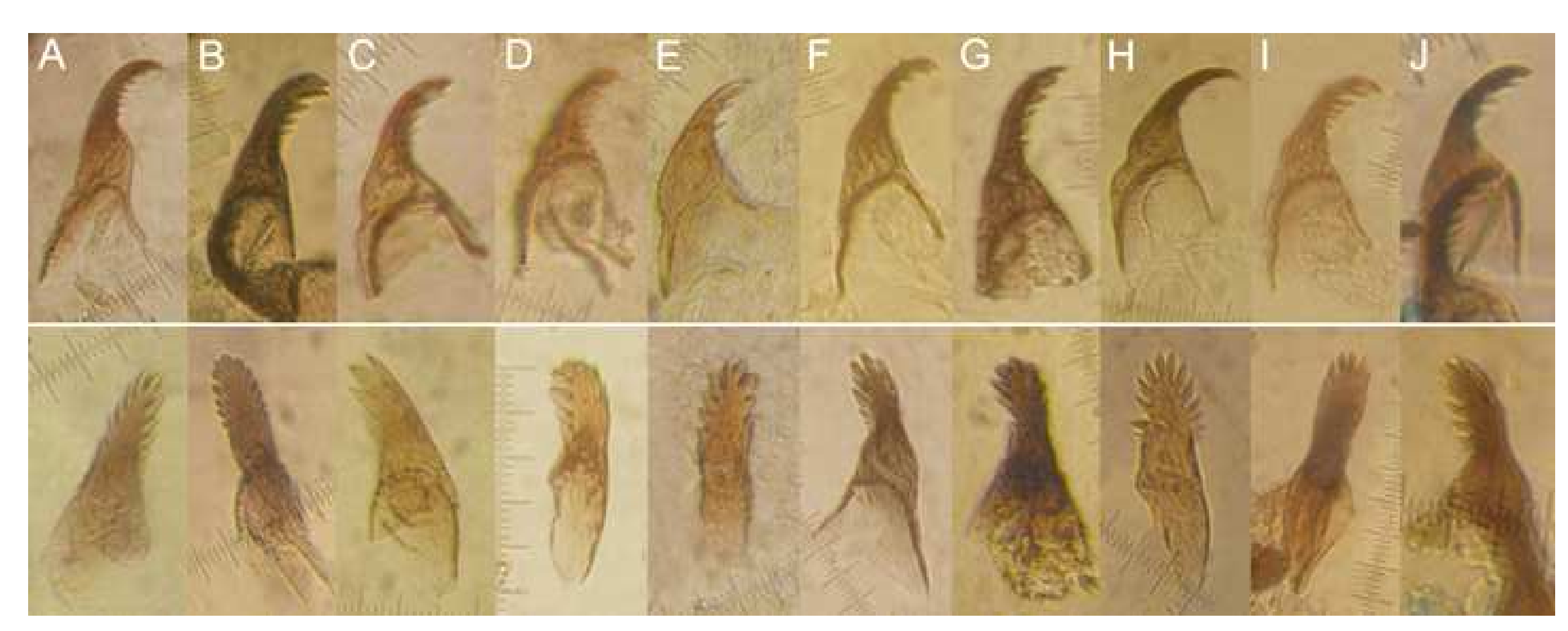




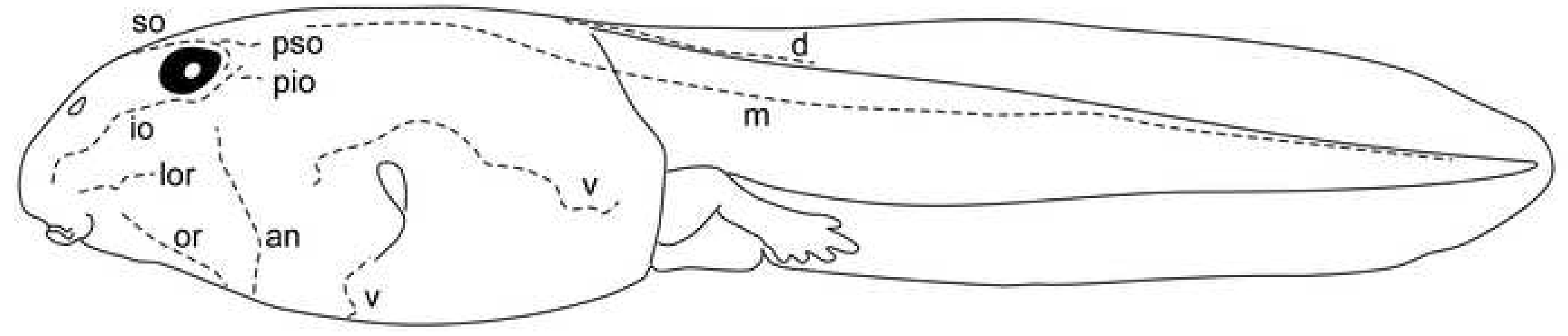


A

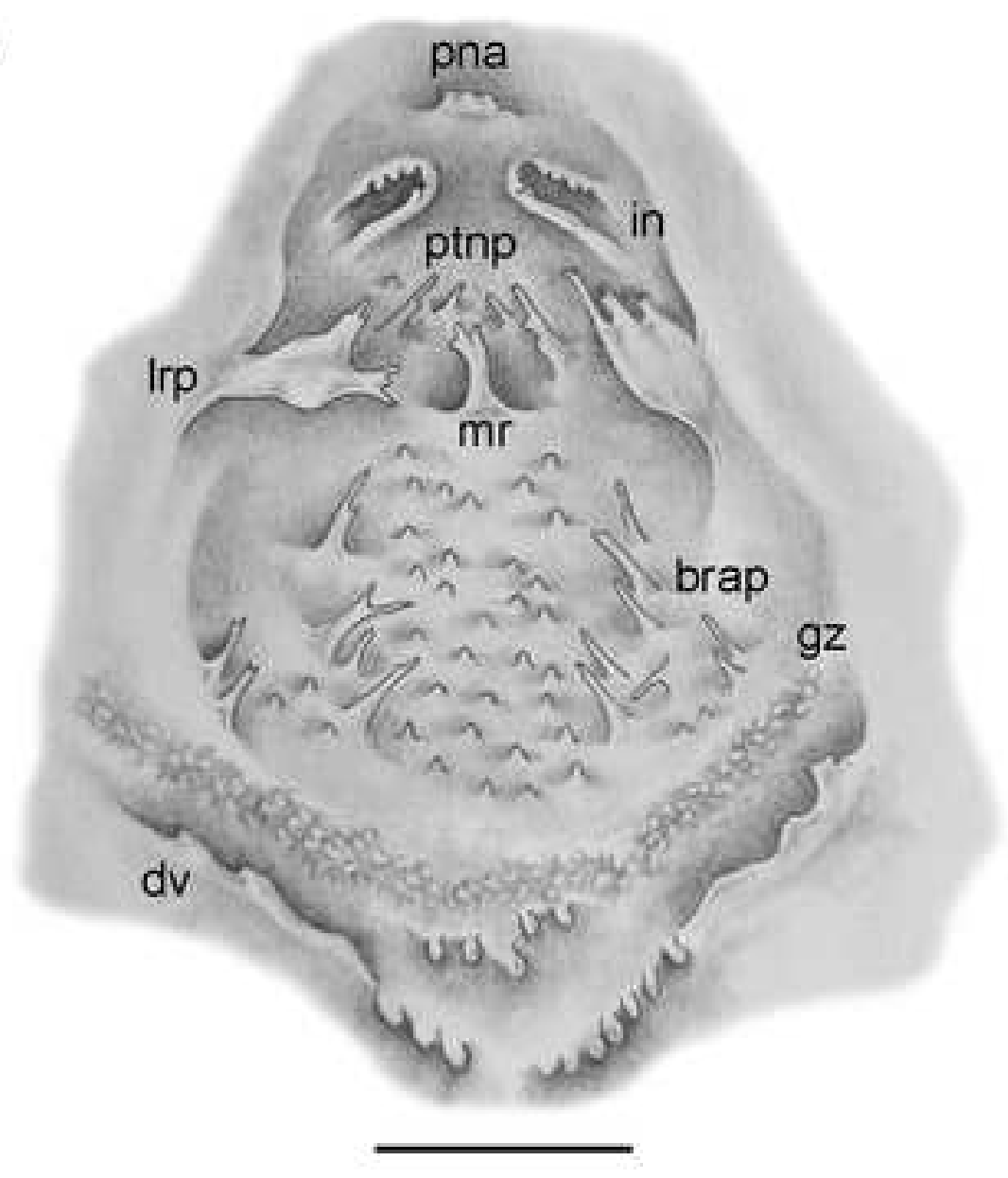

B

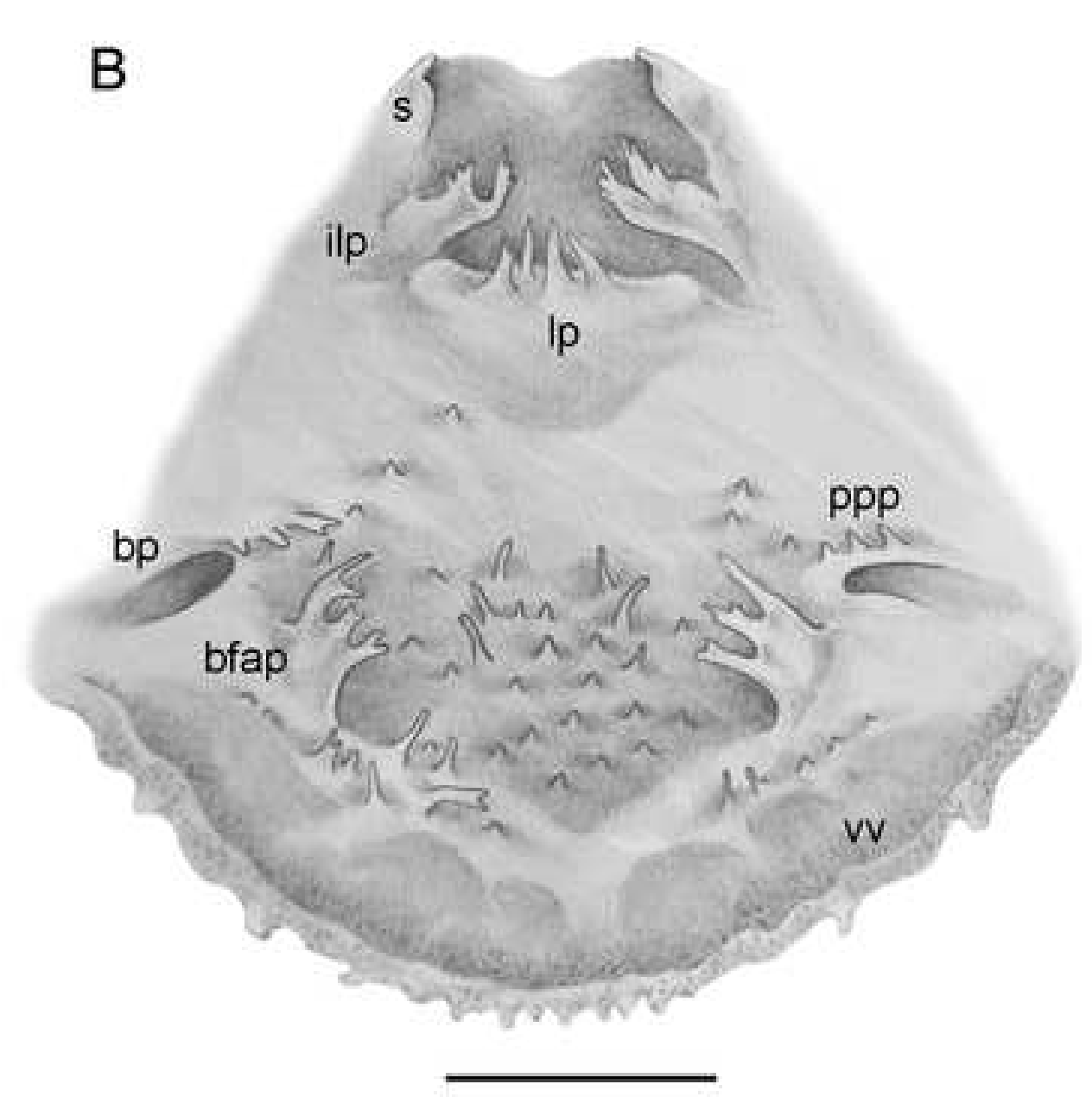




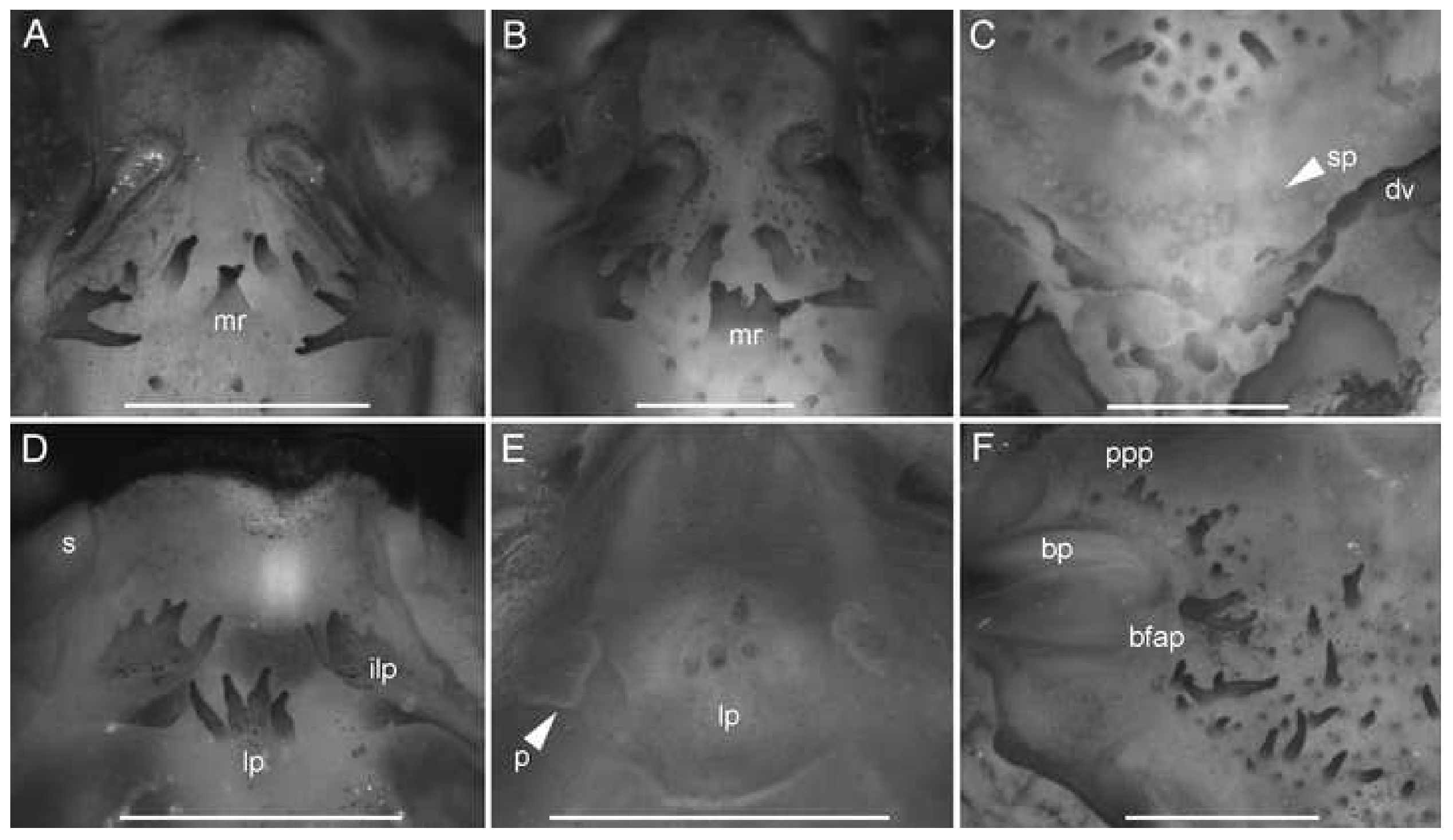



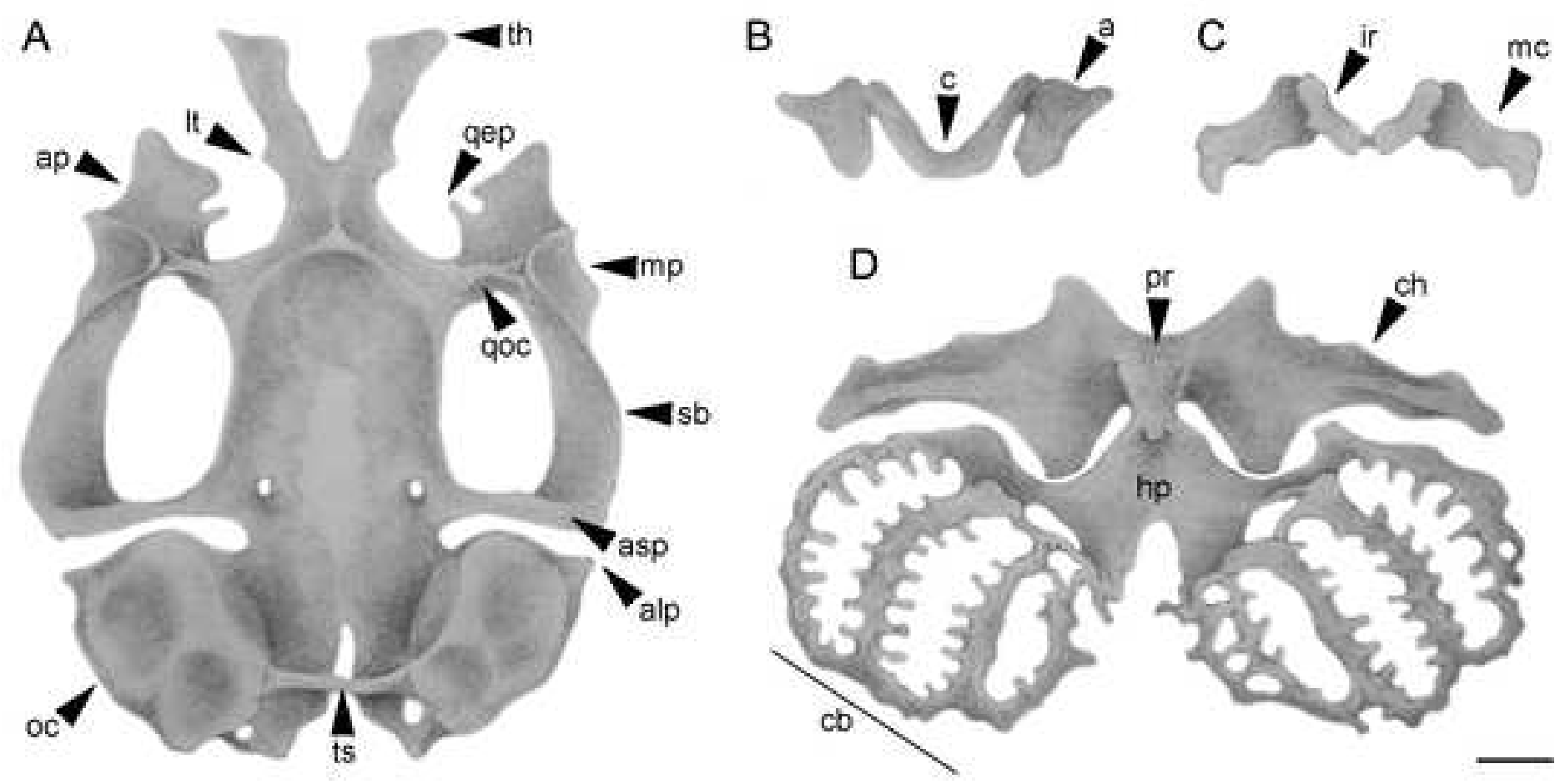

E

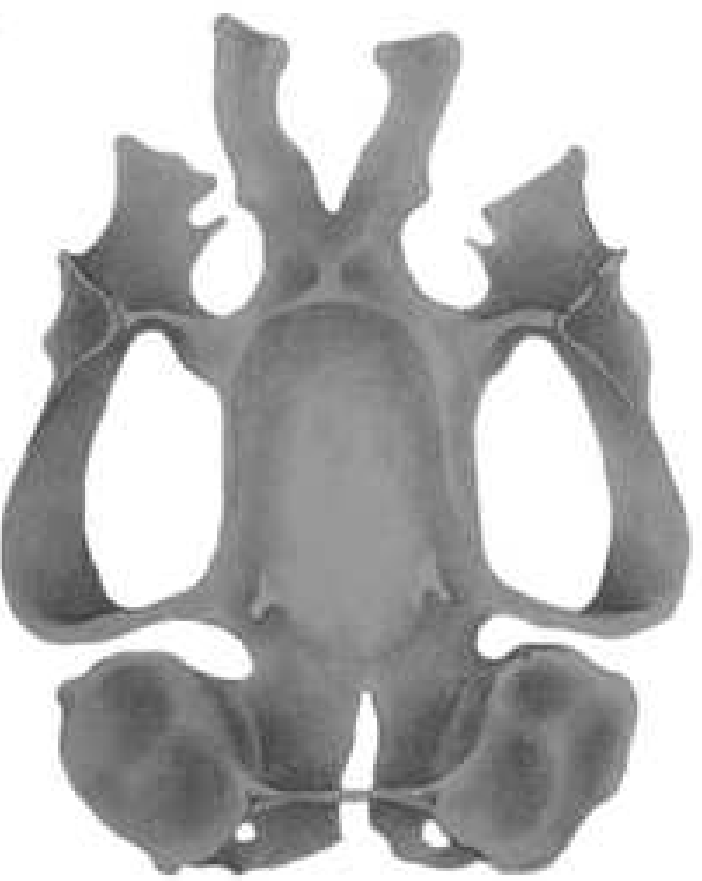

F
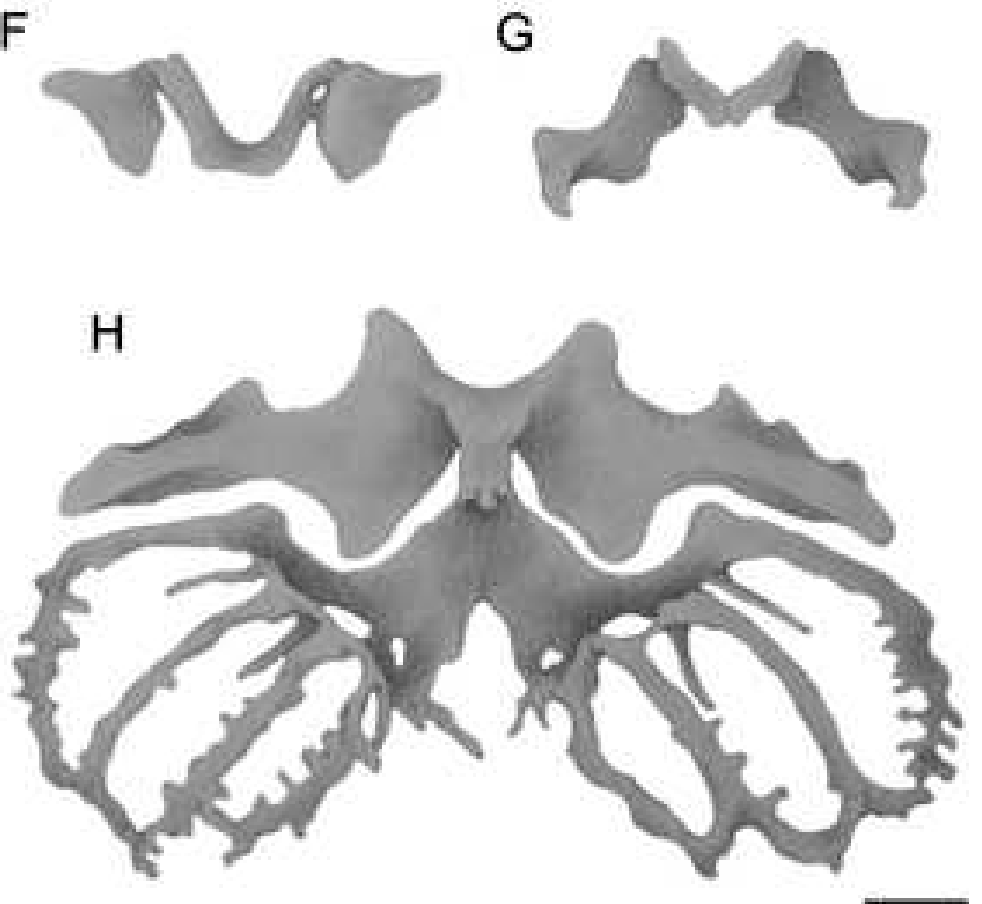

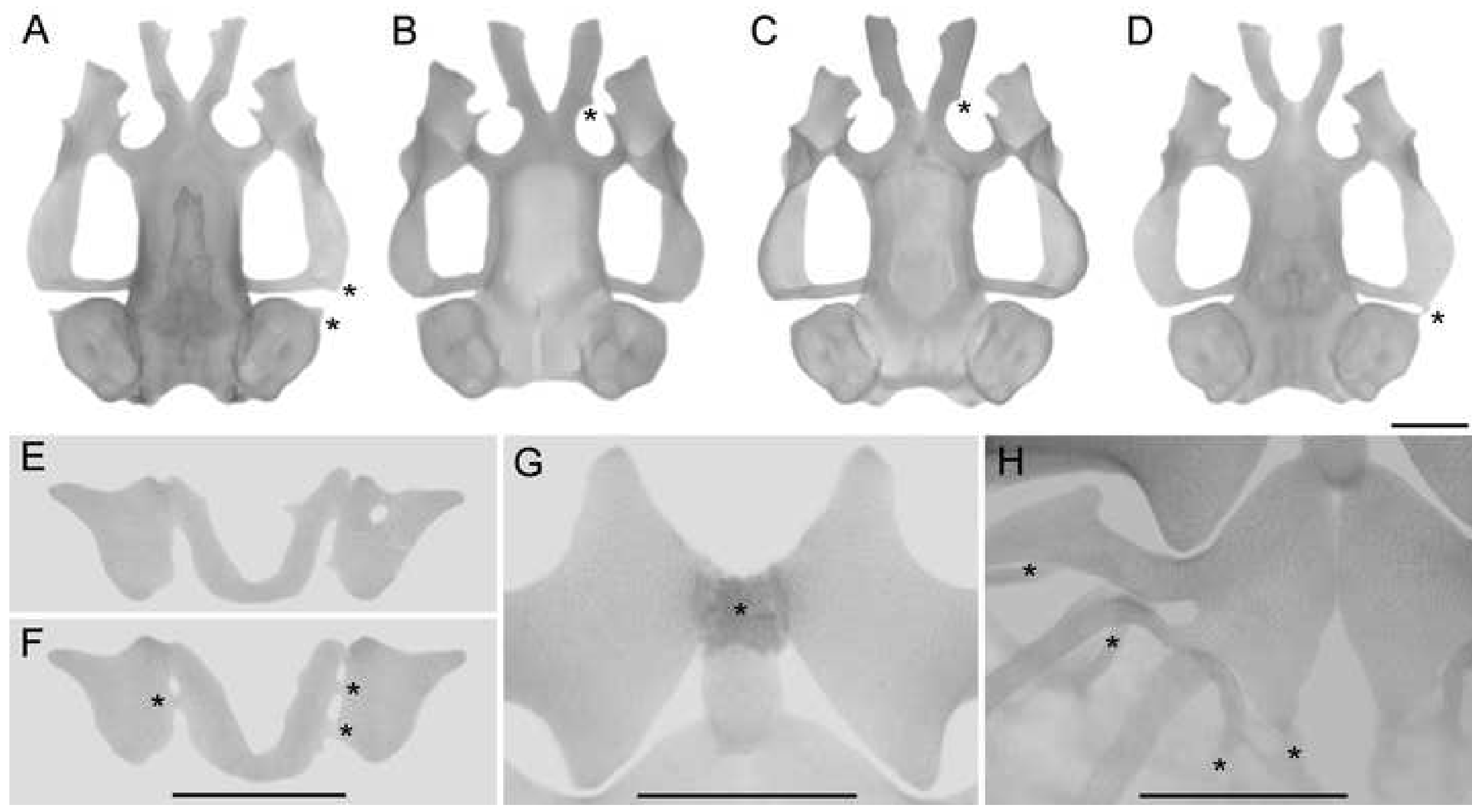
A

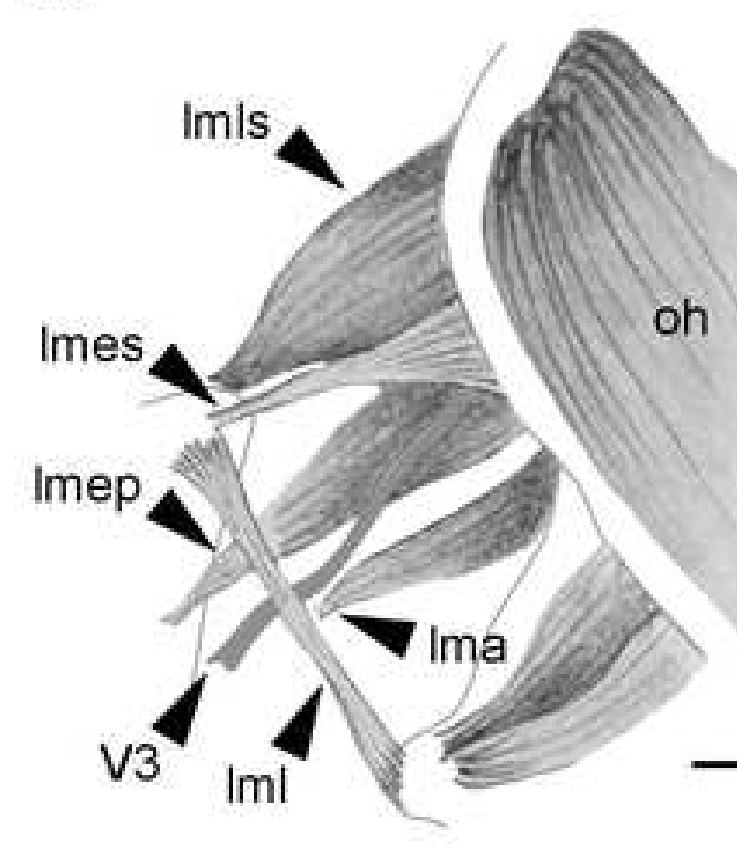

C

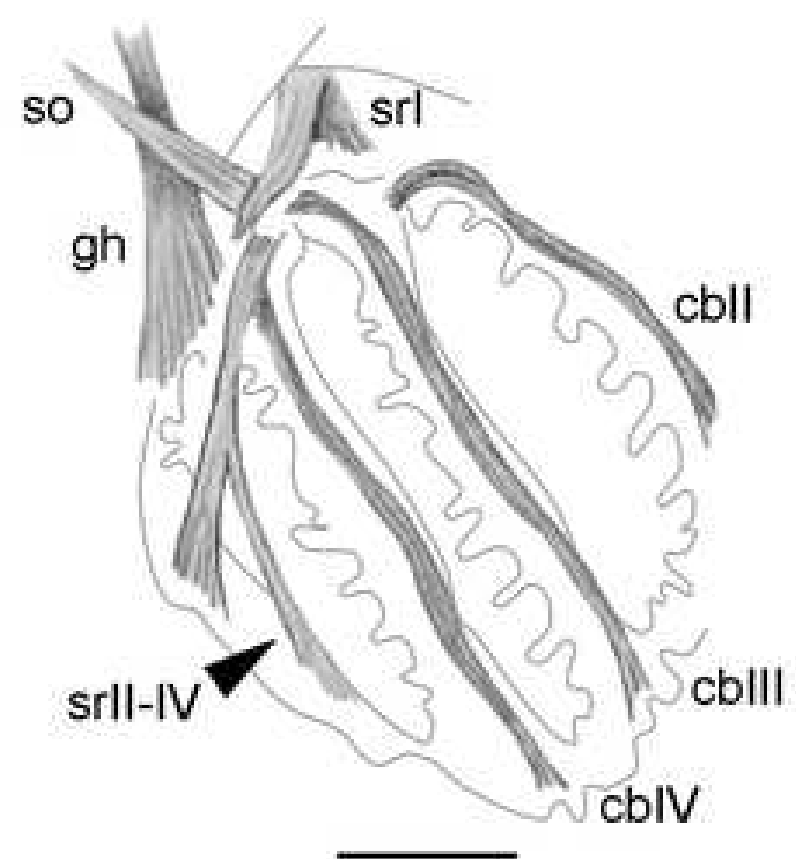

B

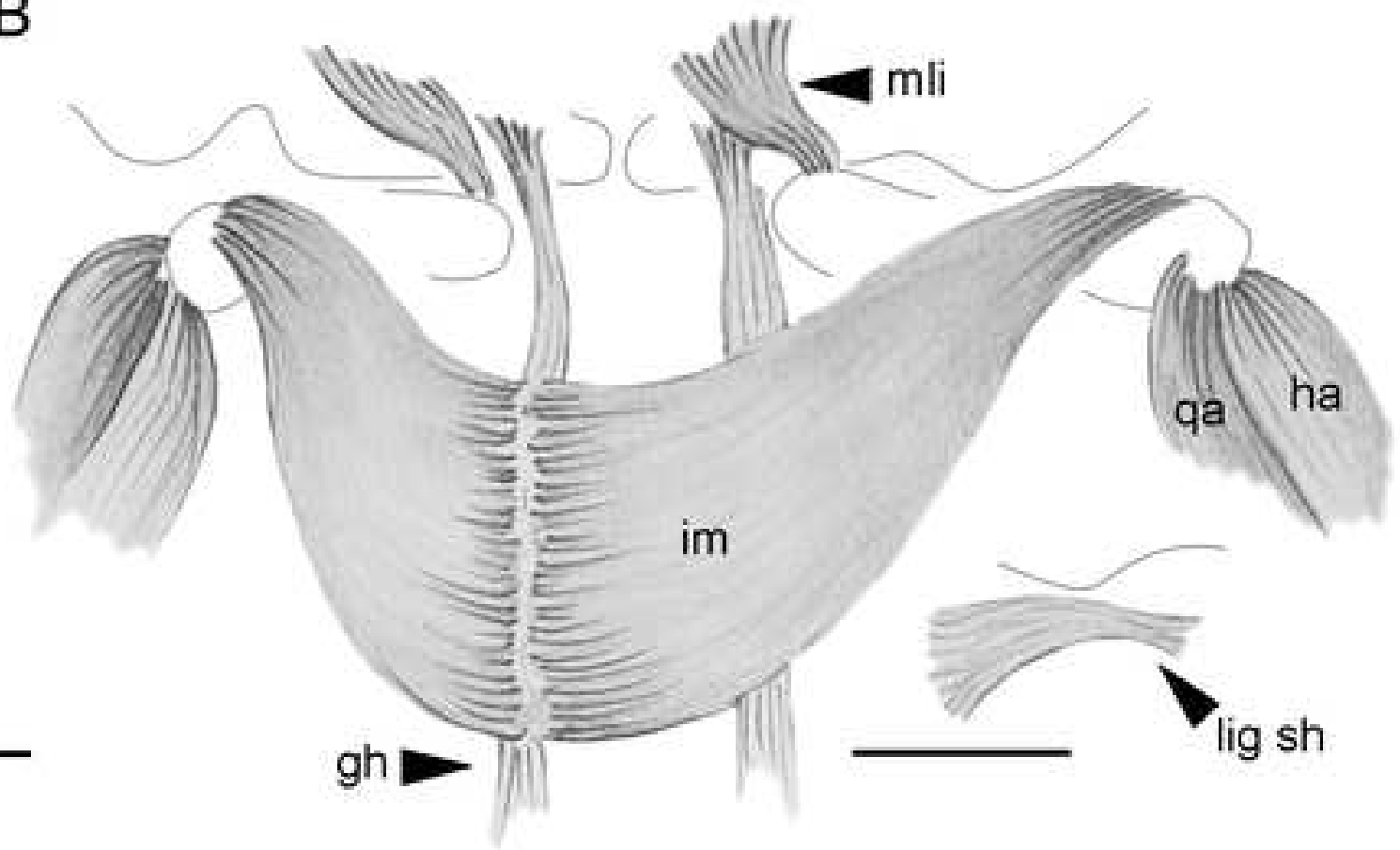

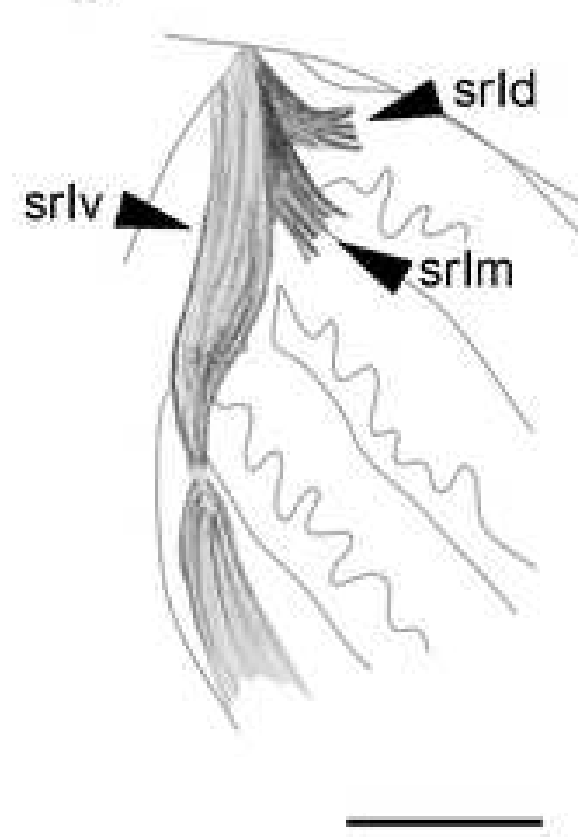

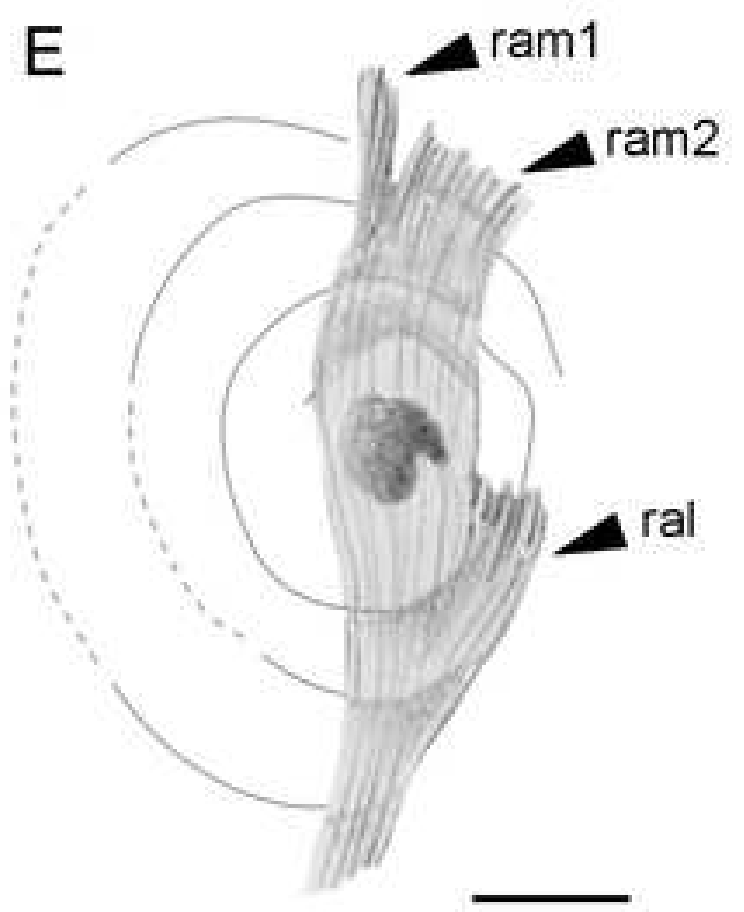

